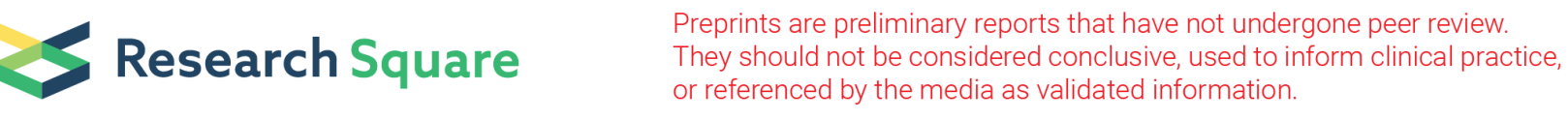

\title{
The association between various biological, behavioural and psychosocial factors and type 2 diabetes mellitus in Africa: a systematic review and meta-analysis
}

Ayuba Issaka ( $\square$ aissaka@deakin.edu.au )

Deakin University - Melbourne Burwood Campus https://orcid.org/0000-0002-1022-3633

Yin Paradies

Deakin University Alfred Deakin Institute for Citizenship and Globalisation

Adrian J Cameron

Deakin University - Geelong Waterfront Campus

Christopher Stevenson

Deakin University - Geelong Waterfront Campus

Research article

Keywords: Type 2 diabetes, Africa, risk factors, psychosocial, meta-analysis

Posted Date: June 4th, 2020

DOI: https://doi.org/10.21203/rs.3.rs-28478/v1

License: () (1) This work is licensed under a Creative Commons Attribution 4.0 International License. Read Full License 


\section{Abstract \\ Background}

Type 2 diabetes mellitus (T2DM) is a significant public health concern in many African countries. While the determinants underpinning T2DM are likely to be Africa-specific, knowledge of these risk factors is largely derived from developed countries. This is the first systematic review and meta-analysis to include biological, behavioural and psychosocial risk factors for T2DM in Africa.

\section{Methods}

Relevant scientific databases were searched, and data were extracted from 66 studies. Fifty- nine studies reported unadjusted data and were analysed using Comprehensive Meta-Analysis (CMA) software version 2.0. The Odds ratios (OR) and their $95 \%$ Cls for the associations between BMI indices (overweight, obesity), central obesity (waist circumference, waist to hip ratio), behavioural (alcohol, fruit and vegetable consumption, smoking), physical inactivity, and psychosocial factors (stress, anxiety, and depression) and T2DM were calculated using a random-effect model. Moderator effects of age, language-spoken, sub-regions and urban/rural location was assessed.

\section{Results}

A number of risk factors were associated with T2DM including, BMI-based definitions of obesity [OR $=3.22,95 \%$ Cl: $92.73,3.80)]$, overweight [OR $=2.22,95 \% \mathrm{Cl}:(1.90,2.58)]$, or overweight/obesity [OR $=2.58,95 \% \mathrm{Cl}:(1.76,3.78)]$; Central obesity as measured by waist circumference [OR $=2.51,95 \% \mathrm{Cl}:(1.86,3.37)]$, or waist to hip ratio [OR $=2.03,95 \% \mathrm{Cl}: 1.51,2.72]$; psychosocial factors which includes stress [OR $=2.2,95 \% \mathrm{Cl}:(1.46,3.31)]$, depression [OR $=2.42,95 \% \mathrm{Cl}:(1.14,3.31)]$ and anxiety [OR $=2.05,95 \%(\mathrm{Cl}: 1.0,4.18)]$ and physical inactivity [OR $=1.88,95 \% \mathrm{Cl}:(1.53,2.23)]$. Current smoker [OR $=1.13,95 \% \mathrm{Cl}:(0.84,1.49)]$, alcohol consumption [OR $=1.10,95 \% \mathrm{Cl}$ : $(0.82,1.47)]$ and inadequate fruit and vegetable consumption $[\mathrm{OR}=0.81,95 \% \mathrm{Cl}:(0.57,1.16)]$ were not associated with T2DM. Locality (urban/rural), language spoken, and sub-region (East/West Africa) did not significantly moderate the associations between the risk factors and T2DM.

\section{Conclusion}

Obesity (defined by BMI) is most strongly associated with T2DM. Overweight, waist circumference and waist to hip ratio, physical inactivity, psychosocial risk factors defined as stress, depression, anxiety were all significantly associated with T2DM. These findings add novel meta-analyses of associations between diverse individual risk factors and T2DM within the African context.

\section{Background}

\section{Introduction}

Diabetes Mellitus (DM) is a major contributor to global mortality and morbidity. Since the 1980s, Africa has seen an emergence of T2DM as an important non-communicable disease (NCD) increasingly threatening the health, political and socio-cultural framework of the continent's population [1, 2]. Across Africa, T2DM prevalence varies significantly within and between countries, geographical location (e.g. urban vs rural) [5, 6] and sub-regions (e.g. East vs West Africa) [4], as well as countries of common or different spoken language (e.g. French vs. English speakers) [3]. Comparative figures show that while the prevalence of diabetes in other continents is expected to increase by between 15\% (Western Pacific) and 84\% (South East Asia) from 2017 to 2045, the prevalence in Africa is predicted to increase by $156 \%$ within the same period [4]. As such, Africa is on the path to bear the most significant burden of T2DM epidemiology including Disability-Adjusted Life Years (DALY), premature death and mortality in the decades ahead [5].

In sub-Saharan Africa (SSA), $69 \%$ of people with T2DM aged 20 to 79 are undiagnosed [6]. This figure is substantially greater than the global figure of $50 \%$ [6]. As such, the majority of Africans with T2DM are diagnosed only after presenting with substantial health complications. This delay in diagnosis, coupled with a lack of access to high-quality healthcare, results in loss of productivity, morbidity, premature death [7], and mortality [8]. The Global Burden of Disease study suggests that all-age total DALY lost due to NCDs including diabetes in SSA, increased by 67\% between 1990 (90.6 million [95\% UI 81·0-101.9]) and 2017 (151.3 million [133.4-171.8])

Page $2 / 27$ 
[5]. Broader knowledge of the relationship between modifiable risk factors and T2DM underpinning this burden and the escalating trend is based predominantly on studies involving Europid and other non-African populations $[9,10]$. Previous studies suggest that the relationship between risk factors such as body weight indicators (e.g. obesity \& waist circumference) and T2DM varies across different populations $[9,11-13]$. The unique racial composition, culture, socioeconomic factors, dietary patterns, political structures, geography and environment in Africa mean that Africa-specific studies of risk factors for T2DM are important. Understanding the African-specific relationships between potentially modifiable risk factors (biological, cultural, behavioural and psychosocial) and T2DM is of critical importance to primary prevention efforts $[2,14,15]$.

Although several primary Africa-specific epidemiological studies have been conducted investigating associations between modifiable risk factors and T2DM [16-35], to date no reviews, to our knowledge, have summarised these studies using a systematic and metaanalytic methodology. This is despite the existence of several Africa-specific T2DM systematic and narrative reviews [36-40], including limited meta-analyses [40-46]. These reviews, however, focused primarily on the epidemiology of T2DM burden (e.g. prevalence, incidence) and their outcomes ( morbidity and mortality) [36-40,47-52] and not on the magnitude of associations. This is the first systematic review and meta-analysis, to our knowledge, to focus on the relationships between a range of biological, behavioural and psychosocial risk factors and T2DM in Africa. This study also considers the role of moderators including age, sex, sub-region (east, west, northern or southern), language spoken, and geographical location (rural vs urban).

\section{Methods}

\section{Design}

This study follows the Preferred Reporting Items for Systematic Reviews and Meta-Analysis (PRISMA) guidelines in reporting of this systematic review and meta-analysis [53].

Figure 1 depicts the PRISMA flow chart. The protocol for this study has been previously published [3] and is registered with PROSPERO (Registration number CRD42016043027).

\section{Search Strategy}

We conducted a database search in English of published quantitative data only. The initial search was conducted in November 2017 with an updated search in February 2019. The search included studies that focused on diabetes and a range of biological, behavioural and psychosocial risk factors within the African context. Please see Additional file 1 for a list of search terms. The search covered scientific databases including Global Health, PsycINFO, CINAHL, MEDLINE, Psychology and Behavioural Science. Reference lists of included articles were searched for additional articles.

\section{Inclusion and Exclusion Criteria}

The study considered articles that reported empirical research, were conducted among populations living in Africa and published in English from 1 January 2000 to 16 February 2019. We included quantitative studies from cross-sectional, longitudinal, cohort and casecontrol that reported associations between T2DM as an outcome measure and the risk factors of interest. Studies were included if T2DM was measured following the 1999 World health organisation (WHO) and the American Diabetes Association (ADA) criteria. The risk factors examined include body weight indicators which include BMI indices [overweight (OV), obesity (OB) and overweight/obesity $(\mathrm{OV} / \mathrm{OB})]$, and central obesity indices (waist circumference (WC) and waist to hip ratio (WHR)]. Others include physical activity (PA), current alcohol consumption (ALC), current smoking (SMO) and psychosocial risk factors (stress, anxiety, and depression).

We excluded studies with outcome measure as type 1 diabetes, impaired glucose tolerance, impaired fasting glucose and gestational diabetes.

For the independent risk factors, we excluded socioeconomic status as a potential risk factor due to its direct link to both nonmodifiable (e.g. age, sex, and ethnicity) and modifiable risk factors (e.g. SMO, ALC, diet, and PA) as opposed to T2DM [54]. We also excluded hypertension and dyslipidaemia as T2DM may causally affect hypertension and dyslipidaemia whereas the opposite relationships are unlikely to be causal $[55,56]$.

Reviews, editorials, commentaries, and letters were excluded. Studies that reported relevant risk factors and T2DM, but not the associations between them, were excluded. Associations with risk factors treated as the outcome measures in multivariate analyses

Page $3 / 27$ 
adjusted for various covariates were also excluded.

\section{Screening}

The search yielded 39,561 studies and results were imported into Endnote Version 9. Duplicates were removed and 30,713 studies remained. The first reviewer (Al) assessed study eligibility for inclusion by initially screening the titles and abstracts. For an article to pass the first stage of screening, the title, and abstract needed to mention diabetes and any of the risk factors. Five hundred and four studies were retained, and full text obtained for the second stage. Another 8 articles were found in the reference lists. At this stage, the articles were further considered if three reviewers (Al, YP, and AC) considered that their abstract showed that the paper may contain quantitative data and an association between the risk factors and T2DM. The observed average agreement between reviewers on the screening at this stage was $95.9 \%$. After completing this stage, a total of 177 studies were retained for the third stage and screened against all criteria including an appropriate measure of associations by the first reviewer and results confirmed by a second reviewer (YP). Final decisions to exclude studies at this stage were discussed by two reviewers (Al and YP) and disagreements were resolved by consensus with third (AC) and fourth (CS) reviewers. The agreement between reviewers at this stage was $97.5 \%$ with 66 studies remaining for data extraction [16-22, 24, 25, 27-34, 57-94] and including both unadjusted and adjusted data (e.g. adjusted for covariates such as age and family history). Only unadjusted data were included in the meta-analysis.

\section{Data extraction and management}

The final 66 studies were reviewed, extracted and coded by the one author (AI), and extracted data were double-checked by YP. We developed a Microsoft Excel spreadsheet and an accompanying manual for this purpose. We then extracted data from studies that reported an unadjusted bivariate association between the risk factors and T2DM as well as studies that adjusted for different covariates. Information extracted from each article includes study design, number of studies ( $\mathrm{k}$ ), year of publication, study participants ( $n$ ), risk factors (e.g. OB) and associations with T2DM for effect size calculations [95]. Others include age, geographical locations (urban, rural), countries and sub-regions, language spoken, sample size, and odds ratio (OR) with confidence intervals (Cl).

The definition of T2DM was based on WHO or ADA criteria, and included a fasting blood glucose (FBG) of $\geq 7.0 \mathrm{mmol} / \mathrm{L}$ ( $126 \mathrm{mg} / \mathrm{dL}$ ), or 2-hour glucose level of $\geq 11.1 \mathrm{mmoL} / \mathrm{L}(200 \mathrm{mg} / \mathrm{dL})$ during a $75 \mathrm{~g}$ oral glucose tolerance test (OGTT) or the glycated haemoglobin (HbA1c) value of C $6.5 \%[96]$.

Definitions of smoking, alcohol and fruit and vegetable consumption adopted for this study have been used extensively in previous reviews [97-100] and include: Current smoking status (yes or no, including former smokers. Current alcohol intake (either i. yes or no; or ii. current drinkers vs. never/non-drinkers). Fruit and vegetable consumption (inadequate vs adequate consumption) and physical activity (vigorous vs low physical). For psychosocial risk factors, the reference group was no stress, depression or anxiety vs. currently having these conditions. Due to the small number of studies for these individual risk factors (stress, anxiety, depression) they were aggregated into a summary variable for psychosocial risk factors.

\section{Data Integration, coding and analysis}

The metrics used in this meta-analysis in measuring associations between the risk factors and T2DM were ORs and 95\% Cls, employed as a measure of the effect size. Other metrics were converted to ORs including cross-tabulation $(2 \times 2)$ of events and non-event (T2DM/ risk factor $\times$ T2DM/no risk factor) as well as Chi-squared. Comprehensive Meta-Analysis (CMA) was used for all conversion, calculations as well as coding the data [101]. Where ORs were lower than 1 (i.e. risk factor was protective), ORs were reverse coded by calculating $1 / 0$ Rs for consistency and ease of interpretation.

Variation in sample sizes was accounted for by calculating weighted effect sizes, giving larger samples more weight. Most studies provided multiple homogenous associations between risk factors and T2DM which were not independent. In resolving the issue of dependence, we used the averaging method to calculate a single effect size per study [102] (i.e., the shifting-unit-of-analysis approach [102]). This approach not only ensured that each study contributes exactly a single independent association per analysis but was more advantageous in retaining as much data as possible $[102,103]$. Since the study aims to generalise the findings, the random effect model was used to calculate the overall effect sizes. For moderator analysis, mixed-effect models were a more conservative approach to test for different moderator levels. Moderation analyses were conducted separately for all risk factors.

\section{Heterogeneity and moderator analysis}


$Q$ and $I^{2}$ statistics were used to assess effect sizes of study heterogeneity [104]. The Q statistics measured the existence of heterogeneity, while the $\mathrm{I}^{2}$ statistics assessed the percentage of study variability due to heterogeneity instead of by chance [104, 105]. $\mathrm{I}^{2}$ values of approximately $50 \%$ and $\geq 75 \%$ were considered moderate and high heterogeneity respectively $[104,105]$. Moderation analysis was used to explain the heterogeneity and interaction effects of the risk factors and T2DM. The strength and directions of these associations were tested using moderators such as study participants' age, sub-regions (East/West Africa), Locality (urban/rural dwelling) and lingua franca (French or English speakers). A moderator variable was analysed if it had at least two levels that were examined in five or more studies [95]. This is based on the established minimum threshold widely used in various meta-analyses [95, $104,106,107]$.

\section{Vote-counting analysis}

This study utilised unadjusted data only and was complemented by summarising the adjusted data using the vote-counting methods. Vote counting is a method of synthesising evidence from multiple estimates by comparing the number of studies with positive results against the number of studies with negative results. However, it does not take into consideration sample size, study quality and effect size [108]. The most common variables adjusted for in this study included hypertension, IFG, age, family history of diabetes, gender, socioeconomic status, education, and marital status [109].

\section{Publication bias analyses}

Using the CMA program, we assessed publication bias in three different ways. First, we checked for bias by producing funnel plots and physically examined any evidence of symmetry. Second, we examine the intercept for significance of the sample of studies for statistical evidence of bias using Egger's test [110]. Thirdly, due to the propensity to publish studies with statistically significant results relative to the non-significant ones, thus "the file drawer problem [111], the Rosenthal's Failsafe number was used to calculate the number of non-significant unpublished (or missing) studies needed to be included to the meta-analysis to change statically significant results to non-significant one [112]. The criterion suggests that, the value of the Failsafe $\mathrm{N}$ should be greater or equal to 5 times the number of included studies in a meta-analysis. The Rosenthal's failsafe $\mathrm{N}$ was also used to decide whether the effect is an artefact of bias or by chance. The Duval and Tweedie trim and fill methods were then used to adjust for detected bias or unpublished (or missing) papers to assess what the effect size would have been given no bias existed $[113,114]$.

\section{Results \\ Descriptive}

An initial search generated a list of 30,713 publications after duplicates were removed. A total of 66 studies met the inclusion criteria, with 59 of them reporting unadjusted data and hence included in the analyses. Tables 1,2, and 3 provide descriptive statistics of study, risk factor, and participant level characteristics respectively. The overall sample size was 181,204 participants. There was a high variation in sample sizes across the 66 studies. Study sample sizes ranged from 90 to 45,767 participants, with $37 \%$ of articles reporting a sample between $50-500$, while $20 \%$ of studies had a sample size between $501-1000$ and $35 \%$ included a sample size between 1001 to 5000. Nine percent of studies had a sample size between 5001-45,767. The included 66 studies were comprised of 328 individual unique associations. Of these associations, 206 were unadjusted from 59 studies. Two articles reported two different studies each in one paper [20,93]. These were comparative studies from multiple countries in Africa. We differentiated these studies by adding study 1 and 2 to each reference. The 66 articles were published between 2000 and 2019. Of these studies, 35 articles were published between 2016 to 2019 (53\%), 23 studies between 2011 to 2015 (35\%), and 8 studies between 2000 to 2010 (12\%). All studies were published in academic peer-reviewed journals. Many of the studies were conducted among West African populations (39\%). Of these, $21 \%$ were published in Nigeria, and others from Ghana (12\%), Senegal (5\%), and Burkina Faso (2\%). This is followed by East Africa, where $38 \%$ of the total studies were published. Among these countries, $11 \%$ were from Ethiopia, or otherwise Uganda $(8 \%)$, Kenya (9\%), Malawi (2\%), Mozambique (2\%), Tanzania (5\%), North Sudan (2\%) and South Sudan (2\%). The majority of the studies used a cross-sectional design ( $86 \%)$. Only 4 studies $(6 \%)[21,66,79,115]$ reported longitudinal data and $6 \%$ were case-control studies $[16,61$, $116,117]$. More studies were conducted in urban areas $(41 \%)$ compared to rural areas $(21 \%)$, with $33 \%$ of studies conducted in both geographical areas. 
Table 1

Study level characteristics

\begin{tabular}{|c|c|c|c|}
\hline Article Level & Groups & Number of article reporting & Percentage \\
\hline \multirow[t]{4}{*}{ Sample Size } & $50-500$ & 24 & $36.6 \%$ \\
\hline & $501-1000$ & 13 & $19.7 \%$ \\
\hline & $1001-5000$ & 23 & $34.8 \%$ \\
\hline & $5001-45,767$ & 6 & $9.1 \%$ \\
\hline \multicolumn{4}{|c|}{ Year of publication } \\
\hline & $2000-2010$ & 8 & $12.1 \%$ \\
\hline & $2011-2015$ & 23 & $34.8 \%$ \\
\hline & $2016-2019$ & 35 & $53.0 \%$ \\
\hline \multicolumn{4}{|c|}{ Type of publication } \\
\hline & Academic journal & 66 & $100.0 \%$ \\
\hline \multicolumn{4}{|l|}{ Sub-regions } \\
\hline \multicolumn{4}{|l|}{ West Africa } \\
\hline & Nigeria & 14 & $21.2 \%$ \\
\hline & Ghana & 8 & $12.1 \%$ \\
\hline & Senegal & 3 & $4.6 \%$ \\
\hline & Burkina Faso & 1 & $1.5 \%$ \\
\hline \multicolumn{4}{|l|}{ Central Africa } \\
\hline & DRC & 3 & $4.6 \%$ \\
\hline & Cameroon & 2 & $3.0 \%$ \\
\hline \multicolumn{4}{|l|}{ East Africa } \\
\hline & Uganda & 5 & $7.6 \%$ \\
\hline & Ethiopia & 7 & $10.6 \%$ \\
\hline & Kenya & 6 & $9.1 \%$ \\
\hline & Malawi & 1 & $1.5 \%$ \\
\hline & Tanzania & 3 & $4.6 \%$ \\
\hline & Mozambique & 1 & $1.5 \%$ \\
\hline & North Sudan & 1 & $1.52 \%$ \\
\hline & South Sudan & 1 & $1.52 \%$ \\
\hline \multicolumn{4}{|c|}{ North \& Southern Africa } \\
\hline & South Africa & 5 & $7.6 \%$ \\
\hline & Seychelles & 1 & $1.5 \%$ \\
\hline & Zambia & 1 & $1.5 \%$ \\
\hline & Morocco & 1 & $1.5 \%$ \\
\hline \multicolumn{4}{|c|}{ Multiple countries } \\
\hline & Kenya, Ghana \& Nigeria & 1 & $1.5 \%$ \\
\hline
\end{tabular}




\begin{tabular}{|c|c|c|c|}
\hline Article Level & Groups & Number of article reporting & Percentage \\
\hline & Uganda and Tanzania & 1 & $1.5 \%$ \\
\hline \multicolumn{4}{|c|}{ Language spoken } \\
\hline & English & 46 & $69.7 \%$ \\
\hline & French & 11 & $16.7 \%$ \\
\hline & Amharic & 7 & $10.6 \%$ \\
\hline & Arabic/English & 2 & $3.0 \%$ \\
\hline \multicolumn{4}{|c|}{ Study type/design } \\
\hline & Cross-sectional & 60 & $90.9 \%$ \\
\hline & Longitudinal & 6 & $9.1 \%$ \\
\hline & Case Control & 4 & $6.1 \%$ \\
\hline & NR & 1 & $1.5 \%$ \\
\hline \multicolumn{4}{|l|}{ Sex } \\
\hline & Male and female & 63 & $95.5 \%$ \\
\hline & Female only & 1 & $1.5 \%$ \\
\hline & Not reported & 2 & $3.0 \%$ \\
\hline \multicolumn{4}{|l|}{ Age } \\
\hline & Adults (18 and above) & 53 & $80.3 \%$ \\
\hline & Mix (12 and above) & 12 & $18.2 \%$ \\
\hline \multicolumn{4}{|l|}{ Urban/Rural } \\
\hline & Both & 22 & $33.3 \%$ \\
\hline & Urban & 27 & $40.9 \%$ \\
\hline & Rural & 14 & $21.2 \%$ \\
\hline & NA & 3 & $4.6 \%$ \\
\hline
\end{tabular}


Table 2

T2DM and risk factor level characteristics

\begin{tabular}{|c|c|c|c|}
\hline T2DM and Risk Factor article Level & Groups & Number of articles reporting & Percentage \\
\hline \multicolumn{4}{|l|}{ T2DM Measure } \\
\hline \multirow[t]{6}{*}{ Biologically Screened } & & 66 & $100.0 \%$ \\
\hline & FPG/RBG & 44 & $66.7 \%$ \\
\hline & OGTT & 2 & $3.0 \%$ \\
\hline & HBA1c & 5 & $7.6 \%$ \\
\hline & Glucose oxidase & 3 & $4.5 \%$ \\
\hline & Mix [Screened (FPG)] and self-report] & 12 & $18.2 \%$ \\
\hline \multicolumn{4}{|l|}{ T2DM Definitions } \\
\hline & WHO only & 45 & $80.4 \%$ \\
\hline & WHO/ADA & 4 & $7.1 \%$ \\
\hline & ADA only & 7 & $12.5 \%$ \\
\hline \multicolumn{4}{|l|}{ Risk Factors } \\
\hline & Overweight (BMI) & 48 & $16.2 \%$ \\
\hline & Obese (BMI) & 46 & $15.5 \%$ \\
\hline & Overweight/Obese (BMI) & 15 & $5.1 \%$ \\
\hline & Obese (WC) & 34 & $11.4 \%$ \\
\hline & Obese (WHR) & 27 & $9.1 \%$ \\
\hline & Physical inactivity & 27 & $9.1 \%$ \\
\hline & Alcohol & 32 & $10.8 \%$ \\
\hline & Smoking & 40 & $13.5 \%$ \\
\hline & Fruit \& Vegetables & 7 & $2.4 \%$ \\
\hline & Fruit only & 7 & $2.4 \%$ \\
\hline & Vegetables only & 4 & $1.3 \%$ \\
\hline & Stress & 2 & $0.7 \%$ \\
\hline & Anxiety & 2 & $0.7 \%$ \\
\hline & Depression & 4 & $1.3 \%$ \\
\hline
\end{tabular}


Table 3

Participant level characteristics

\begin{tabular}{|lll|}
\hline Participant level & Number & Percentage \\
\hline Male & 72,957 & $41.2 \%$ \\
\hline Female & 104,062 & $58.8 \%$ \\
\hline Mix (12 and above) & 30,105 & $17.0 \%$ \\
\hline Adults (18+) & 146,734 & $83.0 \%$ \\
\hline Not reported & 5239 & $3.0 \%$ \\
\hline English & 149,928 & $84.8 \%$ \\
\hline French & 24125 & $13.6 \%$ \\
\hline Other & 5750 & $3.3 \%$ \\
\hline
\end{tabular}

Table 2 shows risk factor and outcome level characteristics. Reported in the 66 studies, almost all 181, 204 participants were biologically screened for T2DM. Forty-three (65\%) of these studies used FBG/RBG [16, 17, 19, 20, 22-30, 34, 57, 58, 60, 61, 64-66, 68, $69,75,77-82,84-89,91,116-122]$. Twelve (18\%) studies reported diabetes diagnosed by both FBG test and self-report [18, 20, 21, 32, $67,73,92,93,115]$. Five studies (8\%) used HBA1c [83, 90, 123-125] while $3(6 \%)$ studies used glucose oxidase test [31, 63, 94], and 2 (3\%) used OGTT test [71, 72].

Among all the risk factors body weight indicators (BMI-OV/OB, BMI-OB, WC, and WHR) were most commonly reported with BMI-OV (16\%) being the most reported overall. This was followed by BMI-OB (15\%) and BMI-OV/OB (5\%), WC (11\%), and WHR (9\%). Lifestyle risk factors reported included smoking (13\%), alcohol consumption (11\%) and fruit and/or vegetable consumption (2\%). Further, 27 studies (9\%) reported physical activity with 18 of these (67\%) using the Global Physical Activity Questionnaire (GPAQ), followed by the General Practitioner physical activity questionnaire (GPPAQ) (7\%), and 15\% used self-reported and occupation assessment. Three percent of the studies examined psychosocial factors (depression, stress, and anxiety) utilising various instruments (pleases see Additional file 2). Five $(8 \%)$ studies $[26,81,90,125,126]$ reported a single association, while $61(92 \%)$ reported associations with multiple risk factors. Table 3. shows participants' characteristics across all studies. All studies reported the sex and age of participants. Of the 181,204 participants, $41 \%$ were males and $59 \%$ were females, $83 \%$ (18 years and above) of the participants were adult and $17 \%$ were young adults (12 years and above), $85 \%$ were English speakers and $14 \%$ were French speakers.

\section{Meta-analysis}

\section{Effect sizes (OR) by risk factors}

The meta-analysis includes 59 studies reported in 57 papers. It comprised of 206 unadjusted associations between modifiable risk factors and T2DM. Table 4 presents the mean of weighted effect size results. This includes three main groups: overall body weight indicators (i.e. BMI indices and central obesity indices), psychosocial factors, and lifestyle risk factors. Among these three groups, the overall body weight indicators had the largest mean weighted effect size $(\mathrm{OR}=2.44,95 \% \mathrm{Cl}:[2.10,2.84] \mathrm{k}=45)$, followed by psychosocial factors $(\mathrm{OR}=2.15, \mathrm{Cl}:[1.51,3.06] \mathrm{k}=4)$. Lifestyle risk factors were not significantly associated with T2DM. 
Table 4

Effect sizes for associations between combined and individual risk factors and T2DM

\begin{tabular}{|c|c|c|c|c|c|c|c|c|c|c|}
\hline Risk factor group & Risk factors & OR & $\begin{array}{l}\text { Lower } \\
\mathrm{Cl}\end{array}$ & $\begin{array}{l}\text { Upper } \\
\text { Cl }\end{array}$ & $\begin{array}{l}\mathrm{Z}- \\
\text { value }\end{array}$ & $\begin{array}{l}\mathrm{P}- \\
\text { value }\end{array}$ & k & $\begin{array}{l}\text { Q- } \\
\text { Value }\end{array}$ & $\begin{array}{l}\mathrm{P} \text { - } \\
\text { value }\end{array}$ & $\begin{array}{l}\text { I- } \\
\text { squared }\end{array}$ \\
\hline \multirow[t]{9}{*}{$\begin{array}{l}\text { Body weight indices } \\
\text { (BWI) }\end{array}$} & BMI-OB & 3.22 & 2.73 & 3.80 & 13.89 & $\dot{0} 001$ & 29 & 62.85 & $<.001$ & 55.45 \\
\hline & $\mathrm{BMI}-\mathrm{OV} / \mathrm{OB}$ & 2.58 & 1.76 & 3.78 & 4.85 & $<0.001$ & 12 & 53.31 & $\begin{array}{l}< \\
0.001\end{array}$ & 79.37 \\
\hline & BMI- OV & 2.22 & 1.9 & 2.58 & 10.18 & $<.001$ & 29 & 70.88 & $\begin{array}{l}< \\
0.001\end{array}$ & 60.5 \\
\hline & $\begin{array}{l}\text { Combined effect(BMI } \\
\text { indices) }\end{array}$ & 2.59 & 2.23 & 3.00 & 12.53 & $<0.001$ & 41 & 114.67 & $\begin{array}{l}< \\
0.001\end{array}$ & 65.12 \\
\hline & Obese (WC) & 2.51 & 1.87 & 3.37 & 6.09 & $<0.001$ & 21 & 152.8 & $\begin{array}{l}<.001 \\
0.00\end{array}$ & 86.91 \\
\hline & Obese (WHR) & 2.03 & 1.51 & 2.72 & 4.73 & $<001$ & 16 & 43.84 & $\begin{array}{l}< \\
0.001\end{array}$ & 65.78 \\
\hline & Combined effect & 2.24 & 1.80 & 2.80 & 7.16 & $<$ & 27 & 115.51 & $<$ & 77.5 \\
\hline & $\begin{array}{l}\text { (Central Obesity } \\
\text { Indices) }\end{array}$ & & & & & 0.001 & & & 0.001 & \\
\hline & Overall effect BWI & 2.44 & 2.1 & 2.84 & 11.47 & $<001$ & 45 & 188.48 & $\begin{array}{l}< \\
0.001\end{array}$ & 76.66 \\
\hline \multirow{4}{*}{$\begin{array}{l}\text { Psychosocial risk } \\
\text { factors (PsyRF) }\end{array}$} & DEP & 2.42 & 1.14 & 5.16 & 2.29 & 0.020 & 4 & 5.22 & 0.160 & 42.48 \\
\hline & STRESS & 2.2 & 1.46 & 3.31 & 3.8 & $<.001$ & 2 & 0.57 & 0.450 & 0.00 \\
\hline & ANX & 2.05 & 1.00 & 4.18 & 1.96 & 0.050 & 2 & 0.53 & 0.470 & 0.00 \\
\hline & Overall effect PsyRF & 2.15 & 1.51 & 3.06 & 4.25 & $<.001$ & 4 & 3.97 & 0.410 & 0.00 \\
\hline \multirow[t]{6}{*}{$\begin{array}{l}\text { Lifestyle Risk factors } \\
\text { (LsRF) }\end{array}$} & ALC & 1.05 & 0.90 & 1.23 & 0.66 & 0.510 & 22 & 76.98 & $\begin{array}{l}< \\
0.001\end{array}$ & 72.72 \\
\hline & SM & 1.12 & 0.84 & 1.49 & 0.75 & 0.450 & 28 & 174.64 & $\begin{array}{l}< \\
0.001\end{array}$ & 84.54 \\
\hline & FR\&VE & 0.81 & 0.57 & 1.16 & -1.15 & 0.520 & 3 & 4 & 0.100 & 76.34 \\
\hline & Overall effect LsRF & 1.10 & 0.91 & 1.27 & 0.84 & 0.400 & 31 & 131.5 & $\begin{array}{l}< \\
0.001\end{array}$ & 77.19 \\
\hline & FR & 0.70 & 0.47 & 1.05 & -1.72 & 0.090 & 7 & 14.32 & 0.030 & 58.12 \\
\hline & VE & 0.92 & 0.55 & 1.54 & 0.34 & 0.740 & 4 & 10.19 & 0.020 & 70.56 \\
\hline Physical inactivity (PA) & PA & 1.88 & 1.53 & 2.32 & 5.94 & $<.001$ & 15 & 32.46 & $\begin{array}{l}<.001 \\
0.01\end{array}$ & 56.87 \\
\hline
\end{tabular}

For the bodyweight indicators, the OR for combined BMI indices (BMI-OV, BMI-OV/OB \& BMI-OB) OR $=2.59,95 \% \mathrm{Cl}$ : $[2.23,3.00 . \mathrm{k}=41]$ was also larger than for the combined central obesity indices (WC \& WHR) $(\mathrm{OR}=2.24,95 \% \mathrm{Cl}$ : $[1.80,2.80] \mathrm{k}=27)$. Figures 2,3 and 4 presents forest plots for the overall body weight indicators, combined BMI indices, and central obesity indices. The mean weighted effect sizes for individual body weight indicators were BMI-OB $(\mathrm{OR}=3.22,95 \% \mathrm{Cl}:(2.73,3.80 . \mathrm{k}=29), \mathrm{BMI}-\mathrm{OV}(\mathrm{OR}=2.22, \mathrm{Cl}:[1.9,2.58] \mathrm{k}$ $=29), \mathrm{BMI}-\mathrm{OV} / \mathrm{OB}(\mathrm{OR}=2.58, \mathrm{Cl}:[1.76,3.38] \mathrm{k}=12)$, WC $(\mathrm{OR}=2.51$, Cl: $[1.86,3.37] \mathrm{k}=21)$ and WHR $(\mathrm{OR}=2.03,95 \% \mathrm{Cl}:([1.51,2.72], \mathrm{k}=$ 17). Except for BMI-OB (see Fig. 5), forest plots are not presented for individual body weight indicators due to space limitations but are available from the authors upon request. 
PA was significantly associated with T2DM (OR $=1.88,95 \% \mathrm{Cl}$ : $[1.53,2.23], \mathrm{k}=15)$; Additional file 3. Similarly, psychosocial risk factors associations with T2DM ranged from OR $=2.05,95 \% \mathrm{Cl}$ : $(1.00,4.18)$ for anxiety to $\mathrm{OR}=2.42,95 \% \mathrm{Cl}:(1.14,5.16)$ for depression.

\section{Publication bias analyses}

The publication bias analysis shows that, apart from BMI-OV/OB, funnel plots for the BMI indices and the other risk factors were comparatively symmetrical. However, the intercept for Egger's regression test was significant for BMI-OV/OB $(p=0.022)$, suggesting potential bias. The non-significant intercepts for the other BMI indices include BMI-OB $(p=0.640)$ and BMI-OV $(p=0.923)$. That of central adiposity were WC $(p=0.0657)$, WHR $(p=0.247)$, lifestyle risk factors ALC $(p=0.427)$, SMO $(p=0.201)$, psychosocial risk factors $(p=0.838)$ and PA ( $p=0.332)$. The Duval and Tweedie trim and fill methods were used to impute 2 studies for BMI-OV/OB resulting in changes to weighted mean effect size (see Additional file 4). This was adjusted from OR=2.58, Cl: $(1.76,3.78)$ to $\mathrm{OR}=3.13 \mathrm{Cl}$ : $(2.01$, 4.87), which remained significant indicating a likelihood of bias, with no significant impact. Further bias analysis using the fail-safe $\mathrm{N}$ indicates that possible bias may exist among the lifestyle risk factors (ALC, SMO, F \& V) as well as psychosocial factors.

\section{Vote-counting analysis}

Vote counting included 28 studies reporting adjusted data with 82 associations between the risk factors and T2DM. Individual body weight indicators made up of $23(82 \%)$ studies with $48(59 \%)$ associations. Of the 82 associations, $50(61 \%)$ reported common covariates, including age, sex, family history, BMI and high blood pressure (HBP). Other covariates adjusted for included ethnicity, sociodemographic and urban-rural migration. $44(92 \%)$ of the 48 associations for the body weight indicators were associated with T2DM with point estimates ranging from $\mathrm{OR}=1.08,95 \% \mathrm{Cl}$ : $(0.50,2.31)$ to $\mathrm{OR}=10.35,95 \% \mathrm{Cl}$ : $(3.34,32.04)$. Of these, 24 were statistically significant (55\%). The other 20 (45\%) associations were not statistically significant.

Among the BMI indices, $\mathrm{BMI}-\mathrm{OB}$ reported a point estimate of 14 associations with T2DM from 12 studies with point estimate ranging from $O R=1.19, \mathrm{Cl}:(0.35,4.05)$ to $\mathrm{OR}=6.55, \mathrm{Cl}: 1.20,35.8)$. Of this, seven were statistically significant with point estimates ranging from $\mathrm{OR}=1.49,95 \% \mathrm{Cl}:(1.26,1.75)$ to $\mathrm{OR}=6.55, \mathrm{Cl}:(1.20,35.8)$. A total of 15 studies reported 17 associations for BMI-OV. Fifteen (83\%) associations showed increased odds of T2DM with point estimates ranging from OR $=1.17,95 \% \mathrm{Cl}:(0.61,2.25)$ to $0 \mathrm{R}: 3.50,95 \% \mathrm{Cl}$ : $(3.20,3.80)$. Of this 6 were significant [ $O R=1.35,95 \% \mathrm{Cl}:(1.16,1.57)$ to $\mathrm{OR}=3.50,95 \% \mathrm{Cl}:(3.20,3.80]$. Among the central obesity indices, WC had 7 associations with T2DM. Five of them were statically significant with increasing odds of T2DM. The point estimate ranges from $\mathrm{OR}=2.23,95 \% \mathrm{Cl}:(1.13,4.40)$ to $\mathrm{OR}=10.35,95 \% \mathrm{Cl}:(3.34,32.04)$. In addition, WHR had 8 associations, all of which showed increased odds of T2DM. The point estimate ranges from OR $=1.08,95 \% \mathrm{Cl}:(0.5,2.31)$ to $\mathrm{OR}=4.6,95 \% \mathrm{Cl}:(1.9,10.9)$. Four $(50 \%)$ associations were significant with point estimates ranging from $\mathrm{OR}=2.63,95 \% \mathrm{Cl}:(1.76,3.93)$ to $\mathrm{OR}=4.6,95 \% \mathrm{Cl}:(1.9,10.9)$.

Further, 8 studies reported 11 associations between PA and T2DM. Of these associations, 8 (73\%) showed increased odds of T2DM. The point estimates ranged from $\mathrm{OR}=1.04,95 \% \mathrm{Cl}:(0.54,3.56)$ to $\mathrm{OR}=4.78$ to $95 \% \mathrm{Cl}:(1.16,19.65)$. Four were statistically significant and ranged from $\mathrm{OR}=1.60,95 \% \mathrm{Cl}(1.10,2.30)$ to $\mathrm{OR}=4.78$ to $95 \% \mathrm{Cl}:(1.16,19.65)$. Finally, for combined smoking, alcohol and fruit and vegetable consumption, a total of 13 studies reported 21 associations. Fourteen (63.6\%) of them showed increased odds with T2DM with point estimates ranging from $\mathrm{OR}=1.03,95 \% \mathrm{Cl}:(0.68,1.58)$ to $\mathrm{OR}=66.9,95 \% \mathrm{Cl}:(28.97,154.49)$. Of these five $(35.7 \%)$ were statistically significant with point estimates from OR $=1.695 \% \mathrm{Cl}:(1.10,2.40)$ to OR $=66.995 \% \mathrm{Cl}$ : $(29,154)$. Three of the significant associations were between smoking and T2DM and one was between alcohol and fruit and vegetable consumption respectively.

\section{Moderator analysis}

The results are shown in Table 5. Analyses were run per risk factor, only when each of the two moderator in question have 5 or more studies [107]. Sub-regions were significant in a pairwise analysis comparing effects for East Africans and the effects of West Africa for central obesity indices combined. The effect of East Africa was larger $(O R=2.80, z=-25.55, p<0.001, k=9)$ than the effect of West Africa $(O R=1.80, z=5.65, p<0.001, k=11), Q(Q 1)=5.22, p=0.022)$. However, for individual central obesity indices, WC was not moderated by sub-regions $Q(1)=2.59, p=0.11$. There was not enough data for WHR to enable such analysis. No other moderators qualified for analysis were significant. 
Table 5

Effect Sizes (OR) for moderators of diabetes risk factors and T2DM

\begin{tabular}{|c|c|c|c|c|c|c|c|c|c|c|}
\hline Moderators & OV & $\mathrm{OB}$ & OV/OB & $\begin{array}{l}\text { Combined } \\
\text { BMI } \\
\text { Indices }\end{array}$ & WC & WHR & $\begin{array}{l}\text { Combined } \\
\text { Central } \\
\text { Obesity }\end{array}$ & $\begin{array}{l}\text { Overall } \\
\text { BWI }\end{array}$ & $\mathrm{AL}$ & SM \\
\hline \multicolumn{11}{|l|}{ Age } \\
\hline $\begin{array}{l}\text { Adults (>= } \\
18 \text { years) }\end{array}$ & $2.20(21)$ & $3.12(22)$ & - & $2.65(30)$ & $2.23(14)$ & $2.27(9)$ & $2.22(18)$ & $2.51(33)$ & - & 1.12 \\
\hline $\begin{array}{l}\text { Mix (12 } \\
\text { and above) }\end{array}$ & $2.29(8)$ & $4.16(7)$ & - & $2.57(10)$ & $3.66(7)$ & $1.66(7)$ & $2.31(9)$ & $2.35(11)$ & - & 1.5 \\
\hline $\begin{array}{l}\text { Between } \\
\text { groups Q }\end{array}$ & 0.05 & 1.45 & - & 0.03 & 2.5 & 1.36 & 2.03 & 0.15 & - & 0.45 \\
\hline \multicolumn{11}{|c|}{ Urban and Rural } \\
\hline Rural & $2.06(6)$ & $3.42(7)$ & - & $2.87(9)$ & $4.18(6)$ & $1.72(6)$ & $2.73(8)$ & $2.40(10)$ & $0.89(5)$ & - \\
\hline Urban & $2.52(12)$ & $3.46(12)$ & - & $2.51(15)$ & $2.02(8)$ & $3.20(6)$ & $2.45(10)$ & $2.06(17)$ & $1.04(11)$ & - \\
\hline $\begin{array}{l}\text { Between } \\
\text { groups Q }\end{array}$ & 0.67 & 0.002 & - & 0.34 & 3.59 & 2.34 & 0.11 & 0.12 & 0.08 & - \\
\hline \multicolumn{11}{|c|}{ Regions in Africa } \\
\hline East & $2.34(11)$ & $3.51(11)$ & $2.14(5)$ & $2.55(17)$ & $3.22(6)$ & - & $2.85(9)$ & $2.44(17)$ & $0.93(7)$ & $1.20(9)$ \\
\hline West & $2.21(10)$ & $3.23(10)$ & $\begin{array}{l}2.43 \\
(5)\end{array}$ & $2.50(14)$ & $2.13(8)$ & - & $1.80(11)$ & $1.86(17)$ & $1.10(12)$ & $1.38(11)$ \\
\hline $\begin{array}{l}\text { Between } \\
\text { groups Q }\end{array}$ & 0.06 & 0.14 & 0.11 & 0.01 & 2.59 & - & $5.22 *$ & 1.72 & 0.64 & 0.12 \\
\hline Central & - & - & - & $4.47(5)$ & - & - & - & $3.30(5)$ & - & - \\
\hline East & - & - & - & $2.62(17)$ & - & - & - & $2.44(18)$ & - & - \\
\hline $\begin{array}{l}\text { Between } \\
\text { groups Q }\end{array}$ & - & - & - & 1.66 & - & - & - & 1.26 & - & - \\
\hline Central & - & - & - & $4.47(5)$ & - & - & - & $3.30(5)$ & - & - \\
\hline West & - & - & - & $2.14(17)$ & - & - & - & $1.86(21)$ & - & - \\
\hline $\begin{array}{l}\text { Between } \\
\text { groups Q }\end{array}$ & - & - & - & 3.17 & - & - & - & 3.17 & - & - \\
\hline \multicolumn{11}{|c|}{ Language spoken } \\
\hline $\begin{array}{l}\text { English } \\
\text { speaking }\end{array}$ & & - & - & $2.44(28)$ & - & - & $2.25(17)$ & $2.32(29)$ & - & - \\
\hline $\begin{array}{l}\text { French } \\
\text { speaking }\end{array}$ & - & - & - & $4.20(5)$ & - & - & $2.45(6)$ & $3.08(8)$ & - & - \\
\hline $\begin{array}{l}\text { Between } \\
\text { groups Q }\end{array}$ & - & - & - & 2.06 & - & - & 0.04 & 1.09 & - & - \\
\hline $\begin{array}{l}\text { OV-Overweig } \\
\text { hip ratio; Con } \\
\text { smoking; Nur } \\
\text { least one leve }\end{array}$ & $\begin{array}{l}\text { t; OB-Obes } \\
\text { bined Cent } \\
\text { hbers insid } \\
\text { l of the mo }\end{array}$ & $\begin{array}{l}\text { y; OV/OB- } \\
\text { al Obesity- } \\
\text { parenthese } \\
\text { erator. }{ }^{*} p<\end{array}$ & $\begin{array}{l}\text { rweigh } \\
+ \text { WHR } \\
\text { re stud }\end{array}$ & $\begin{array}{l}\text { or Obese; } \mathrm{BI} \\
\text {; AL -Alcoho } \\
\text { es 'numbers }\end{array}$ & $\begin{array}{l}\text { indices- } \\
\text { BWl- Over } \\
\text { - Not av }\end{array}$ & $\begin{array}{l}+\mathrm{OB}+\mathrm{O} \\
\text { body wei } \\
\text { able due }\end{array}$ & $\begin{array}{l}\text { OB); WC-Y } \\
\text { t indices;(C) } \\
\text { insufficien }\end{array}$ & $\begin{array}{l}t \text { circum } \\
\text { OB + O } \\
\text { mber of }\end{array}$ & $\begin{array}{l}\text { ence; WHR } \\
\mathrm{JB}+\mathrm{WC}+\mathrm{V} \\
\text { udies }(\mathrm{k}<5\end{array}$ & $\begin{array}{l}\text { Vaist to } \\
\text { HR); SM- } \\
\text { in at }\end{array}$ \\
\hline
\end{tabular}

\section{Discussion}

We conducted the first systematic review and meta-analysis focusing on a range of biological, behavioural as well as psychosocial factors and their associations with T2DM in Africa. Consistent with other systematic reviews and meta-analyses [95, 127-129], publication outputs have increased over time [130]. The greatest number of studies were from West and East Africa. The present study 
showed that all body weight indicators (both BMI and central obesity defined), physical activity and psychosocial factors were significantly associated with T2DM with associations of varying strength. Obesity (defined by BMI) was found to have the strongest association with increased odds for T2DM of more than 3-fold that of any other body weight measures including waist circumference.

These general observations are consistent with some [131], but not all [132] prior meta-analyses. Findings from the present study are consistent with the study by Vazquez et al. [131] among populations from Mauritius, USA (including African Americans), Asia, and Europe. They are also mostly consistent with the study by Kodama et al. [132] among European subjects, however that study did suggest a stronger association between waist circumference and diabetes than that between obesity (defined by BMI) and T2DM. Waist circumference is a stronger indicator of intra-abdominal visceral fat than BMI, and closely linked to insulin resistance and hyperinsulinemia [133]. Interestingly, our findings of a stronger association between BMI and T2DM has also been documented in other pathophysiological studies in African using methods such as dual energy X-ray absorptiometry [134, 135]. Studies in South African women suggest that, for the same BMI, African women have less central fat, but greater peripheral fat accumulation than Caucasian women [133-135]. Sumner et al. [136] also show that increasing waist circumference results in less visceral adipose tissue among African-American and African women than Caucasian women. Although these findings were predominantly from studies among women, they may partly explain why the strength of the association between obesity (defined by BMI) and T2DM is stronger in this study than waist circumference.

The independent role of central obesity in insulin resistance in populations of African descent must not be discounted, however. For example, while detailed examination of the overall body weight indicators shows comparatively larger effect size for the relationship between combined $\mathrm{BMI}$ indices (BMI-OV, BMI-OV/OB, and $\mathrm{BMI}-\mathrm{OB})(\mathrm{OR}=2.59)$ and T2DM compared to the combined central obesity indices (WC and WHR) $(\mathrm{OR}=2.24)$, a strong and independent association between central adiposity and T2DM was evident [137]. This may suggest that either WC or BMI alone could be used as risk factors for T2DM among Africans. The use of a measuring tape alone to assess WC may be appealing in a setting where resources are minimal [138]. A further issue which may have affected our findings in relation to associations between waist circumference and T2DM is the high heterogeneity $\left(I^{2}=87\right)$ of studies, which could not be explained by the moderation analysis. In addition, although meta-analyses have suggested a stronger association between $\mathrm{BMI}$ and diabetes in women than men $[131,139]$, this could not be assessed in the present study due to too few studies reporting findings separately for females and males.

Our analysis of physical activity indicates an almost two-fold increase in odds of T2DM for those who are inactive. After adjusting for publication bias, the magnitude remained the same. These findings are congruent with previous meta-analyses among populations from China, the USA, and Australia that have explored associations of medium to vigorous physical activity and T2DM [140]. While the present study focused on vigorous physical activity and T2DM, other reviews included alternative physical activity measures such as walking, leisure-time activity, resistance activity, occupational activities, low, moderate and vigorous-intensity activity [141]. These measures are important within the African context since physical activity patterns in Africa are somewhat different from industrialised countries [142]. Low to moderate activities are most prevalent within Africa [142]. Although beyond the scope of this paper, an in-depth comparative examination of these differences is required within the African context.

Psychosocial factors in this study were found to increase the odds of T2DM by more than 2-fold with a combined OR $=2.15$. These findings are consistent with various meta-analytic reviews in non-African populations that explored relationships between psychosocial factors and diabetes [143]. A study by Smith et al. [97] in North Americans (includes Whites, African Americans, Hispanic and Chinese), European, Middle-Eastern and Asian populations found that anxiety increased the odds of diabetes by almost one and a half fold, while that of Ali et al. [144] among a population from the USA, Europe (the Netherlands, Finland, and Italy) and Iraq found that depression increased the odds of diabetes by almost one and a half fold. In the present study, however, the small sample size of depression $(k=4)$, stress $(k=2)$ and anxiety $(k=2)$ may have limited power to detect the association with T2DM. As such these findings should be treated as preliminary and interpreted with caution. Again, a fine-grained longitudinal study examining the individual psychosocial risk factors (stress, depression, and anxiety) in the African context is required given evidence of differential associations with T2DM.

Findings of the lifestyle risk factors showed that in this African sample, associations between fruit and vegetable intake, alcohol consumption, and smoking and T2DM were not significant. However, various studies among non-African populations have shown otherwise. A meta-analysis of longitudinal studies among populations from the United States, Japan, United Kingdom, Germany, Israel, and the Scandinavian countries, showed that active smoking is associated with an increased risk of type 2 diabetes [100]. Similarly, a meta-analysis of longitudinal studies among populations from Europe, USA, Australia, Korea and Japan showed a U-shaped relationship between alcohol consumption and diabetes for both men and women, with a greater protective effect of moderate 
consumption observed for women [145]. The non-significant findings of the present study may be partly due to the simpler definitions used in many African studies. Assessing consumption levels based on a report of "Yes" or "No" is likely to not be precise enough to detect an effect, particularly where the association is not strong, or there is a U-shaped association $[145,146]$.

Studies on diet quality show that adherence to the appropriate diet can improve insulin sensitivity and glycaemic control. The current study had data on fruit only and vegetable consumption only, which are protective factors for diabetes. However, only two studies presented associations for fruit and vegetable intake combined, and no study had data on consumption of discretionary, typically ultraprocessed, unhealthy foods, which are strongly related to higher body weight and diabetes[147, 148]. As such, we were unable to confirm the link between diet and T2DM among the African populations. There is a clear need for further studies (preferably longitudinal) assessing the complex association between diet and the incidence of Type 2 diabetes in Africa [149].

These findings were supported by the adjusted data synthesised by the vote-counting analyses, specifically with regards to the more significant results including all body weight indicators. Most moderation analyses were non-significant except for the combined central obesity indices which were moderated by locality (East and West Africa). However, no other moderator was significant. This implies that the risk of acquiring T2DM is independent of geographical location (urban/rural) and spoken language in Africa.

\section{Strengths and Limitations}

There are several limitations associated with this study that should be considered when interpreting the findings. First, only studies published in English were included and thus may under-represent studies predominantly from the Arabic, Portuguese and Frenchspeaking countries in Africa. The use of only unadjusted data may constitute a limitation due to challenges posed by adjusted covariate for systematic reviews and meta-analysis [127]. However, previous systematic reviews and meta-analyses reported nonsignificant findings between unadjusted bivariate and those adjusted for different covariate [132, 150]. Further studies can also explore moderations using meta-regression. In this study, various diabetes definitions were used among the included studies. However, it is unlikely that these differences in definition would have had any impact on the results as the aim of this study was to determine the associations between the risk factors and T2DM, and not the optimal cut-point for each risk factor [138].

The absence of study quality assessments in this study is another potential limitation. Using a critical appraisal tool for meta-analytic studies exploring risk factors and T2DM have been rare, due to challenges posed by observational studies with diverse methodologies. It is also possible different study qualities from individual studies may affect the association between risk factors and T2DM. For example, the observed association between physical activity and diabetes in Africa may have been influenced by using different measurement approaches as well as other confounders used in individual studies. In particular, the different instruments used may constitute a limitation as in the case of psychosocial factors where no two studies used the same tool. Nevertheless, the influence of unknown residual confounders can also not be ignored in individual studies (particularly the lifestyle risk factors) as this may affect the results. There is an urgent need for quality data, particularly on lifestyle risk factors. In sum, there is urgent need of longitudinal studies with a probability sampling technique to systematically measure both risk factors and T2DM, particularly alcohol, smoking, psychosocial factors, unhealthy food, and a range of relevant risk factors in Africa.

Our study has many strengths which include the systematic nature of the review and the use of comprehensive meta-analytic methods, which have not been used to determine the strength of association between risk factors and T2DM in Africa previously. Finally, the large sample size of the study provides high power and precision in our estimates.

\section{Conclusion}

This study constitutes the first comprehensive systematic review and meta-analysis of the association between a range of biological, behavioural, and psychosocial risk factors and diabetes in Africa to date. These findings add novel meta-analyses of associations between diverse individual risk factors and T2DM. Risk factors including obesity (defined by BMI), overweight (defined by BMI), and overweight/obesity (defined by BMI); central obesity (defined by waist circumference and waist to hip ratio), physical activity, psychosocial risk factors (stress, depression, anxiety) were all significantly associated with T2DM. The present study shows that, unlike for studies of European populations, obesity, as defined by BMI, was the factor most strongly associated with T2DM.

This research provides an update on the associations between a range of factors and diabetes in Africa. This is a growing field of research as confirmed by the increased rate of publications over time. While this metanalysis has identified gaps in the literature, we 
hope that this metanalysis provides renewed attention and novel directions for future studies in understanding modifiable risk factors and their role in tackling the escalating burden of T2DM in Africa [151].

\section{Abbreviations}

AL: Alcohol; ANX: Anxiety; BMI: Body mass index; Cl: Confidence interval; CMA: Comprehensive Meta-Analysis; DALY: Disability-Adjusted Life years; DEP: Depression; FR: Fruit; FBG: Fasting blood glucose; GPPAQ: General Practitioner physical activity questionnaire; (GPAQ) Global Physical Activity Questionnaire; HBA1c: Glycated haemoglobin; IDF: International Diabetes Federation; IFG: Impaired Fasting Glucose; NCD: Noncommunicable disease; OB: Obesity; OGTT: Oral glucose tolerant test; OR: Odds ratio OV: Overweight; OV/OB: Overweight or Obese; PA: Physical activity; PRISMA: Preferred Reporting Items for Systematic Reviews and Meta-Analysis; PROSPERO: International Prospective Register of Systematic Reviews; PsyRF: psychosocial risk factors; RBG: Random blood glucose; SD: Standard deviation; STR: Stress; SM: smoking; SSA: Sub-Saharan Africa; T2DM: Type 2 diabetes mellitus; WHO: World Health Organization; VE: Vegetables; WC: Waist circumference; WHR: Waist to hip ratio.

\section{Declarations}

\section{Ethics approval and consent to participate}

Not applicable.

\section{Consent for publication}

Not applicable.

\section{Availability of data and materials}

All data used generated or analysed during this study are available from the corresponding author on reasonable request.

\section{Competing interest}

The authors declare that they have no competing interests.

\section{Funding}

This study was funded by the Australian Government through the Higher Degree Research Program Award and forms part of Ayuba Issaka (Al) PhD thesis. The Australian Government did not play any role in the study design, curation, analysis, visualisation or writing of the manuscript.

\section{Author Contributions}

Al and YP conceived and designed the study. Al curated, analysed and visualised the data and wrote the original draft of the manuscript. Al, YP, AC and CS were involved in screening of studies and reviewed the manuscript. Al edited the manuscript. All Authors read and approved the final manuscript.

\section{Acknowledgments}

The authors would like to thank Jehonathan Ben for his thoughts on methodology and analysis in early versions of the manuscript, and Rachel West for library advice.

\section{References}

1. Renzaho AMN. The post-2015 development agenda for diabetes in sub-Saharan Africa: challenges and future directions. Global Health Action. 2015;8:27600-0. 
2. Trends in obesity and diabetes across Africa from 1980 to 2014: an analysis of pooled population-based studies \% International journal of epidemiology. 2017, 46(5):1421-1432.

3. Issaka A, Paradies Y, Stevenson C. Modifiable and emerging risk factors for type 2 diabetes in Africa: a systematic review and meta-analysis protocol. Systematic reviews. 2018;7(1):139.

4. IDF Diabetes Atlas: International Diabetes Federation, Brussels. 2017. Available from:[Last accessed: 7th February 2018].

5. Gouda HN, Charlson F, Sorsdahl K, Ahmadzada S, Ferrari AJ, Erskine H, Leung J, Santamauro D, Lund C, Aminde LNJTLGH. Burden of non-communicable diseases in sub-Saharan Africa, 1990-2017: results from the Global Burden of Disease Study 2017. 2019, 7(10):e1375-e1387.

6. Cho N, Shaw J, Karuranga S, Huang Y, da Rocha Fernandes J, Ohlrogge A. Malanda BJDr, practice c: IDF Diabetes Atlas: Global estimates of diabetes prevalence for 2017 and projections for 2045. 2018, 138:271-281.

7. Lozano R, Naghavi M, Foreman K, Lim S, Shibuya K, Aboyans V, Abraham J, Adair T, Aggarwal R, Ahn SY. Global and regional mortality from 235 causes of death for 20 age groups in 1990 and 2010: a systematic analysis for the Global Burden of Disease Study 2010. The Lancet. 2013;380(9859):2095-128.

8. Murray CJ, Vos T, Lozano R, Naghavi M, Flaxman AD, Michaud C, Ezzati M, Shibuya K, Salomon JA, Abdalla S. Disability-adjusted life years (DALYs) for 291 diseases and injuries in 21 regions, 1990-2010: a systematic analysis for the Global Burden of Disease Study 2010. The lancet. 2013;380(9859):2197-223.

9. Yusuf S, Hawken S, Ôunpuu S, Dans T, Avezum A, Lanas F, McQueen M, Budaj A, Pais P, Varigos JJTI. Effect of potentially modifiable risk factors associated with myocardial infarction in 52 countries (the INTERHEART study): case-control study. 2004, 364(9438):937-952.

10. Unwin N, Setel P, Rashid S, Mugusi F, Mbanya J-C, Kitange H, Hayes L, Edwards R, Aspray T, Alberti K. Noncommunicable diseases in sub-Saharan Africa: where do they feature in the health research agenda? Bulletin of the World Health organization. 2001;79(10):947-53.

11. Ashwell M, Gunn P, Gibson, SJOr. Waist-to-height ratio is a better screening tool than waist circumference and BMI for adult cardiometabolic risk factors: systematic review and meta-analysis. 2012, 13(3):275-286.

12. Wang S, Ma W, Yuan Z, Wang S-m, Yi X, Jia H, Xue FJBo. Association between obesity indices and type 2 diabetes mellitus among middle-aged and elderly people in Jinan, China: a cross-sectional study. 2016, 6(11):e012742.

13. Feng R-N, Zhao C, Wang C, Niu Y-C, Li K, Guo F-C, Li S-T, Sun C-H. Li YJJoe: BMI is strongly associated with hypertension, and waist circumference is strongly associated with type 2 diabetes and dyslipidemia, in northern Chinese adults. 2012, 22(4):317-323.

14. Peer N, Kengne A-P, Motala AA, Mbanya JC. Diabetes in the Africa region: An update. Diabetes Research Clinical Practice. 2014;103(2):197-205.

15. Levitt N, Steyn K, Lambert E, Reagon G, Lombard C, Fourie J, Rossouw K, Hoffman M. Modifiable risk factors for Type 2 diabetes mellitus in a peri-urban community in South Africa. Diabet Med. 1999;16(11):946-50.

16. Adebamowo SN, Adeyemo AA, Tekola-Ayele F, Doumatey AP, Bentley AR, Chen G, Zhou J, Shriner D, Fasanmade OA, Okafor G, et al: Impact of type 2 diabetes on impaired kidney function in sub-saharan African populations. Frontiers in Endocrinology 2016, 7(MAY).

17. Ala OA, Akintunde AA, Ikem RT, Kolawole BA, Ala OO, Adedeji TA. Association between insulin resistance and total plasma homocysteine levels in type 2 diabetes mellitus patients in south west Nigeria. Diabetes and Metabolic Syndrome: Clinical Research and Reviews 2017.

18. Alikor CA, Emem-Chioma PC. EPIDEMIOLOGY OF DIABETES AND IMPAIRED FASTING GLUCOSE IN A RURAL COMMUNITY OF NIGERIAN NIGER DELTA REGION. Nigerian Journal Of Medicine: Journal Of The National Association Of Resident Doctors Of Nigeria. 2015;24(2):114-24.

19. Bahendeka S, Wesonga R, Mutungi G, Muwonge J, Neema S, Guwatudde D. Prevalence and correlates of diabetes mellitus in Uganda: A population-based national survey. Tropical Medicine International Health. 2016;21(3):405-16.

20. Bailey SL, Ayles H, Beyers N, Godfrey-Faussett P, Muyoyeta M, du Toit E, Yudkin JS, Floyd S. Diabetes mellitus in Zambia and the Western Cape province of South Africa: Prevalence, risk factors, diagnosis and management. Diabetes Res Clin Pract. 2016;118:111.

21. Bastawrous A, Mathenge W, Wing K, Bastawrous M, Rono H, Weiss HA, Macleod D, Foster A, Peto T, Blows P, et al. The incidence of diabetes mellitus and diabetic retinopathy in a population-based cohort study of people age 50 years and over in Nakuru, Kenya. 
BMC Endocrine Disorders. 2017;17:1-14.

22. Bello-Ovosi BO, Asuke S, Abdulrahman SO, Ibrahim MS, Ovosi JO, Ogunsina MA, Anumah FO. Prevalence and correlates of hypertension and diabetes mellitus in an urban community in North-Western Nigeria. The Pan African Medical Journal $2018,29$.

23. Chiwanga FS, Njelekela MA, Diamond MB, Bajunirwe F, Guwatudde D, Nankya-Mutyoba J, Kalyesubula R, Adebamowo C, Ajayi I, Reid TG, et al. Urban and rural prevalence of diabetes and pre-diabetes and risk factors associated with diabetes in Tanzania and Uganda. Global Health Action. 2016;9:31440-0.

24. Duboz P, Boëtsch G, Gueye L, Macia E. Type 2 diabetes in a Senegalese rural area. World Journal of Diabetes. 2017;8(7):351-7.

25. Habtewold TD, Tsega WD, Wale BY: Diabetes Mellitus in Outpatients in Debre Berhan Referral Hospital, Ethiopia. Journal of Diabetes Research 2016, 2016.

26. Isa SE, Oche AO, Kang'Ombe AR, Okopi JA, Idoko JA, Cuevas LE, Gill GV. Human Immunodeficiency Virus and Risk of Type 2 Diabetes in a Large Adult Cohort in Jos, Nigeria. Clin Infect Dis. 2016;63(6):830-5.

27. Millogo T, Bicaba BW, Soubeiga JK, Dabiré E, Médah I. Kouanda SJBph: Diabetes and abnormal glucose regulation in the adult population of Burkina Faso: prevalence and predictors. 2018, 18(1):350.

28. Tesfaye T, Shikur B, Shimels T, Firdu N. Prevalence and factors associated with diabetes mellitus and impaired fasting glucose level among members of federal police commission residing in Addis Ababa, Ethiopia. BMC Endocrine Disorders 2016, 16(1).

29. Danquah I, Bedu-Addo G, Terpe K-J, Micah F, Amoako YA, Awuku YA, Dietz E, van der Giet M, Spranger J, Mockenhaupt FP. Diabetes mellitus type 2 in urban Ghana: characteristics and associated factors. BMC Public Health. 2012;12:210-0.

30. Ekpenyong CE, Akpan UP, Ibu JO, Nyebuk DE. Gender and age specific prevalence and associated risk factors of type 2 diabetes mellitus in Uyo metropolis, South Eastern Nigeria. Diabetologia Croatica. 2012;41(1):17-28.

31. Etukumana EA, Puepet FH, Obadofin MO. Risk factors for diabetes mellitus among rural adults in Nigeria. Nigerian Journal Of Medicine: Journal Of The National Association Of Resident Doctors Of Nigeria. 2014;23(3):213-9.

32. Gatoa WE, Acquahb S, Apentengc BA, Opokuc ST, Boakyed BK. Diabetes in the Cape Coast metropolis of Ghana: An assessment of risk factors, nutritional practices and lifestyle changes. International Health. 2017;9(5):310-6.

33. Kyari F, Tafida A, Sivasubramaniam S, Murthy GV, Peto T, Gilbert CE, Murthy GVS. Prevalence and risk factors for diabetes and diabetic retinopathy: results from the Nigeria national blindness and visual impairment survey. BMC Public Health. 2014;14(1):1299-9.

34. Mathenge W, Bastawrous A, Peto T, Leung I, Yorston D, Foster A, Kuper H. Prevalence and correlates of diabetic retinopathy in a population-based survey of older people in nakuru, Kenya. Ophthalmic Epidemiol. 2014;21(3):169-77.

35. Matsha TE, Hassan MS, Kidd M, Erasmus RT. The 30-year cardiovascular risk profile of South Africans with diagnosed diabetes, undiagnosed diabetes, pre-diabetes or normoglycaemia: The Bellville, South Africa pilot study. Cardiovascular Journal of Africa. 2012;23(1):5-11.

36. Alebiosu CO, Odusan O, Familoni OB, Jaiyesimi AEA. Cardiovascular risk factors in type 2 diabetic Nigerians with clinical diabetic nephropathy: cardiovascular topics. Cardiovascular Journal of South Africa. 2004;15(3):124-8.

37. AlGeffari MA, Almogbel ES, Alhomaidan HT, ElMergawi R, Barrimah IA. Glycemic indices, glycemic load and glycemic response for seventeen varieties of dates grown in Saudi Arabia. Ann Saudi Med. 2016;36(6):397-403.

38. Aspray TJ, Unwin N. Diabetes in sub-Saharan Africa. In. 2001;498:21-6.

39. Azevedo M, Alla S. Diabetes in Sub-Saharan Africa: Kenya, Mali, Mozambique, Nigeria, South Africa and Zambia. International Journal of Diabetes in Developing Countries. 2008;28(4):101-8.

40. Chivese T, Werfalli MM, Magodoro I, Chinhoyi RL, Kengne AP, Norris SA, Levitt NSJBo: Prevalence of type 2 diabetes mellitus in women of childbearing age in Africa during 2000-2016: a systematic review and meta-analysis. 2019, 9(5):e024345.

41. Abubakari A-R, Lauder W, Jones M, Kirk A, Agyemang C, Bhopal R. Prevalence and time trends in diabetes and physical inactivity among adult West African populations: the epidemic has arrived. Public Health. 2009;123(9):602-14.

42. Adeloye D, Ige JO, Aderemi AV, Adeleye N, Amoo EO, Auta A, Oni GJBo: Estimating the prevalence, hospitalisation and mortality from type 2 diabetes mellitus in Nigeria: a systematic review and meta-analysis. 2017, 7(5):e015424.

43. Asamoah-Boaheng M, Sarfo-Kantanka O, Tuffour AB, Eghan B, Mbanya JCJIh: Prevalence and risk factors for diabetes mellitus among adults in Ghana: a systematic review and meta-analysis. 2018, 11(2):83-92.

44. Hilawe EH, Yatsuya H, Kawaguchi L, Aoyama A: Differences by sex in the prevalence of diabetes mellitus, impaired fasting glycaemia and impaired glucose tolerance in sub-Saharan Africa: a systematic review and meta-analysis. Bulletin of the World

Page 17/27 
Health Organization 2013, 91(9):671-682D.

45. Uloko AE, Musa BM, Ramalan MA, Gezawa ID, Puepet FH, Uloko AT, Borodo MM, Sada KBJDT: Prevalence and risk factors for diabetes mellitus in Nigeria: A systematic review and meta-analysis. 2018, 9(3):1307-1316.

46. Mutowo M, Gowda U, Mangwiro JC, Lorgelly P, Owen A, Renzaho A. Prevalence of diabetes in Zimbabwe: a systematic review with meta-analysis. Int J Public Health. 2015;60(1):1-11.

47. Kengne AP, Echouffo-Tcheugui JB. Added value of novel biomarkers in type 2 diabetes predictions: Systematic review. J Hypertens. 2012;30:e265.

48. Lachat C, Otchere S, Roberfroid D, Abdulai A, Seret FMA, Milesevic J, Xuereb G, Candeias V, Kolsteren P. Diet and Physical Activity for the Prevention of Noncommunicable Diseases in Low- and Middle-Income Countries: A Systematic Policy Review. PLoS Medicine 2013, 10(6).

49. Lamri L, Gripiotis E, Ferrario A. Diabetes in Algeria and challenges for health policy: A literature review of prevalence, cost, management and outcomes of diabetes and its complications. Globalization and Health 2014, 10(1).

50. Motala AA, Omar MAK, Pirie FJ. Diabetes in Africa. Epidemiology of type 1 and type 2 diabetes in Africa. Journal Of Cardiovascular Risk. 2003;10(2):77-83.

51. Motala AA, Omar MAK, Pirie FJ. Epidemiology of type 1 and type 2 diabetes in africa. J Cardiovasc Risk. 2003;10(2):77-83.

52. Prioreschi A, Munthali RJ, Soepnel L, Goldstein JA, Micklesfield LK, Aronoff DM, Norris SA. Incidence and prevalence of type 2 diabetes mellitus with HIV infection in Africa: A systematic review and meta-analysis. BMJ Open 2017, 7(3).

53. Fleming PS, Seehra J, Polychronopoulou A, Fedorowicz Z, Pandis NJTAO. A PRISMA assessment of the reporting quality of systematic reviews in orthodontics. 2012, 83(1):158-163.

54. Riley L, Guthold R, Cowan M, Savin S, Bhatti L, Armstrong T, Bonita RJAjoph: The World Health Organization STEPwise approach to noncommunicable disease risk-factor surveillance: methods, challenges, and opportunities. 2016, 106(1):74-78.

55. Sun D, Zhou T, Heianza Y, Li X, Fan M, Fonseca VA, Qi, LJCr. Type 2 diabetes and hypertension: a study on bidirectional causality. 2019, 124(6):930-937.

56. Almeida Abdo J, Cirano FR, Casati MZ, Ribeiro FV, Giampaoli V, Viana Casarin RC, Pimentel SPJJop: Influence of dyslipidemia and diabetes mellitus on chronic periodontal disease. 2013, 84(10):1401-1408.

57. Abebe SM, Berhane Y, Worku A, Assefa A. Diabetes mellitus in North West Ethiopia: a community based study. BMC Public Health. 2014;14:97-7.

58. Abebe SM, Getachew A, Fasika S, Bayisa M, Demisse AG, Mesfin N. Diabetes mellitus among HIV-infected individuals in follow-up care at University of Gondar Hospital, Northwest Ethiopia. BMJ Open 2016, 6(8).

59. Adegoke OA, Emma-Okon BO, Abiona TA, Fasanya MK, Tomi-Olugbodi AA. Prevalence of diabetes mellitus and impaired glucose tolerance among freshmen in a Nigerian University. Clin Chem. 2011;57(10):A193.

60. Aladeniyi I, Adeniyi OV, Fawole O, Adeolu M, Goon DT, Ajayi Al, Iruedo J. The prevalence and correlates of pre-diabetes and diabetes mellitus among public category workers in Akure, Nigeria. Open Public Health Journal. 2017;10:167-76.

61. Ali S, Abera S, Mihret A, Abebe T: Association of hepatitis c virus infection with type Il diabetes in ethiopia: A hospital-based casecontrol study. Interdisciplinary Perspectives on Infectious Diseases 2012, 2012.

62. Alkassabany YM, Farghaly AG, El-Ghitany EM. Prevalence, risk factors, and predictors of nonalcoholic fatty liver disease among schoolchildren: A hospital-based study in Alexandria, Egypt. Arab Journal of Gastroenterology. 2014;15(2):76-81.

63. Araya G, Mistire W, Dawit Y. Hypertension, obesity and central obesity in diabetics and non diabetics in Southern Ethiopia. Ethiopian Journal of Health Development. 2010;24(2):145-7.

64. Arugu G, Maduka OJNjocp. Risk factors for diabetes mellitus among adult residents of a rural District in Southern Nigeria: Implications for prevention and control. 2017, 20(12):1544-1549.

65. Divala OH, Amberbir A, Ismail Z, Beyene T, Garone D, Pfaff C, Singano V, Akello H, Joshua M, Nyirenda MJ, et al. The burden of hypertension, diabetes mellitus, and cardiovascular risk factors among adult Malawians in HIV care: consequences for integrated services. BMC Public Health. 2016;16(1):1243-3.

66. Domingo AK, Asmal L, Seedat S, Esterhuizen TM, Laurence C, Volmink J. Investigating the association between diabetes mellitus, depression and psychological distress in a cohort of South African teachers. South African Medical Journal. 2015;105(12):105760. 
67. Duboz P, Chapuis-Lucciani N, Boëtsch G, Gueye L. Prevalence of diabetes and associated risk factors in a Senegalese urban (Dakar) population. Diabetes Metabolism. 2012;38(4):332-6.

68. Ekeke N, Ukwaja KN, Chukwu JN, Nwafor CC, Meka AO, Egbagbe EE, Soyinka FO, Alobu I, Agujiobi I, Akingbesote S, et al. Screening for diabetes mellitus among tuberculosis patients in Southern Nigeria: a multi-centre implementation study under programme settings. Sci Rep. 2017;7:44205-5.

69. Elmadhoun WM, Noor SK, Ibrahim AAA, Bushara SO, Ahmed MH. Prevalence of diabetes mellitus and its risk factors in urban communities of north Sudan: Population-based study. Journal of Diabetes. 2016;8(6):839-46.

70. Ezeala-Adikaibe BA, Mbadiwe N, Okwara C, Onodugo O, Onyekonwu C, ljoma U, Ekenze OS, Orjioke C, Chime P. Aneke EJJoDM: Diabetes and Pre-Diabetes among Adults in an Urban Slum in South East Nigeria. 2018, 8(4):131-144.

71. Faeh D, William J, Tappy L, Ravussin E, Bovet P. Prevalence, awareness and control of diabetes in the Seychelles and relationship with excess body weight. BMC Public Health 2007, 7.

72. Faurholt-Jepsen D, Range N, PrayGod G, Jeremiah K, Faurholt-Jepsen M, Aabye MG, Changalucha J, Ritz C, Christensen DL, Jørgensen ME, et al. The association between conventional risk factors and diabetes is weak among urban Tanzanians. Diabetes Care. 2014;37(1):e5-6.

73. Gatimu SM, Milimo BW, Sebastian MS. Prevalence and determinants of diabetes among older adults in Ghana. BMC Public Health. 2016;16(1):1174-4.

74. Gezawa I, Puepet F, Mubi B, Uloko A, Bakki B, Talle M, Haliru IJSMJ. Socio-demographic and anthropometric risk factors for type 2 diabetes in Maiduguri, North-Eastern Nigeria. 2015, 18(5):1.

75. Gudjinu HY, Sarfo B. Risk factors for type 2 diabetes mellitus among out-patients in Ho, the Volta regional capital of Ghana: a casecontrol study. BMC Research Notes. 2017;10(1):324-4.

76. Hapunda G, Abubakar A, Pouwer F, van de Vijver F. Diabetes mellitus and comorbid depression in Zambia. Diabet Med. 2015;32(6):814-8.

77. Isara AR, Okundia POJTPAmj. The burden of hypertension and diabetes mellitus in rural communities in southern Nigeria. 2015, 20.

78. Kamara NT, Asiimwe S. Dyslipidaemia and hypertension among adults with diabetes in rural Uganda. Trop Doct. 2010;40(1):41-2.

79. Katchunga PB, Cikomola J, Tshongo C, Baleke A, Kaishusha D, Mirindi P, Tamburhe T, Kluyskens Y, Sadiki A, Bwanamudogo S, et al: Obesity and diabetes mellitus association in rural community of Katana, South Kivu, in Eastern Democratic Republic of Congo: Bukavu Observ Cohort Study Results. BMC Endocrine Disorders 2016, 16(1).

80. Katte JC, Kengne AP, Dzudie A, Kouam Kouam C, Mbong E, Dongmo N, Fetse G, Sobngwi E, Mbanya JC. Coincidence of diabetes mellitus and hypertension in a semi-urban Cameroonian population. Diabetes Res Clin Pract. 2014;103:39.

81. Kibirige D, Ssekitoleko R, Mutebi E, Worodria W. Overt diabetes mellitus among newly diagnosed Ugandan tuberculosis patients: A cross sectional study. Am J Trop Med Hyg. 2013;89(5):123.

82. Kingue S, Rakotoarimanana S, Rabearivony N, Bompera FL. Prevalence of selected cardiometabolic risk factors among adults in urban and semi-urban hospitals in four sub-Saharan African countries. Cardiovascular Journal Of Africa. 2017;28(3):147-53.

83. Kizor-Akaraiwe N, Ezegwui I, Oguego N, Uche N, Asimadu I, Shiweobi J. Prevalence, Awareness and Determinants of Diabetic Retinopathy in a Screening Centre in Nigeria. J Community Health. 2016;41(4):767-71.

84. Maher D, Waswa L, Baisley K, Karabarinde A, Unwin N, Grosskurth H. Distribution of hyperglycaemia and related cardiovascular disease risk factors in low-income countries: A cross-sectional population-based survey in rural Uganda. Int J Epidemiol. 2011;40(1):160-71.

85. Mayega RW, Guwatudde D, Makumbi F, Nakwagala FN, Peterson S, Tomson G, Ostenson CG. Diabetes and Pre-Diabetes among Persons Aged 35 to 60 Years in Eastern Uganda: Prevalence and Associated Factors. PLoS ONE 2013, 8(8).

86. Mbamukonka PK, Agasa SB, Tonen-Wolyec S, Mukonkole JPM, Tshilumba CK: Type 2 diabetes mellitus among the elderly in Goma, Democratic Republic of the Congo: prevalence, clinical features and complications. 2017.

87. Mosaku K, Kolawole B, Mume C, Ikem R. Depression, anxiety and quality of life among diabetic patients: A comparative study. J Natl Med Assoc. 2008;100(1):73-8.

88. Nyenwe EA, Odia OJ, Ihekwaba AE, Ojule A, Babatunde S. Type 2 diabetes in adult Nigerians: A study of its prevalence and risk factors in Port Harcourt, Nigeria. Diabetes Res Clin Pract. 2003;62(3):177-85. 
89. On'Kin JBKL, Longo-Mbenza B, Okwe N, Kabangu NK, Mpandamadi SD, Wemankoy O, He J. Prevalence and risk factors of diabetes mellitus in Kinshasa Hinterland. International Journal of Diabetes Metabolism. 2008;16(3):97-106.

90. Owiti P, Keter A, Harries AD, Pastakia S, Wambugu C, Kirui N, Kasera G, Momanyi R, Masini E, Some F, et al. Diabetes and prediabetes in tuberculosis patients in western Kenya using point-of-care glycated haemoglobin. Public Health Action. 2017;7(2):14754.

91. Rguibi M, Belahsen R. Prevalence and associated risk factors of undiagnosed diabetes among adult Moroccan Sahraoui women. Public Health Nutrition. 2006;9(6):722-7.

92. Seck SM, Dia DG, Doupa D, Diop-Dia A, Thiam I, Ndong M, Gueye L: Diabetes Burden in Urban and Rural Senegalese Populations: A Cross-Sectional Study in 2012. International Journal of Endocrinology 2015, 2015.

93. Tarekegne FE, Padyab M, Schroders J, Stewart Williams J. Sociodemographic and behavioral characteristics associated with selfreported diagnosed diabetes mellitus in adults aged 50 + years in Ghana and South Africa: results from the WHO-SAGE wave 1. BMJ Open Diabetes Res Care. 2018;6(1):e000449.

94. Vuvor F, Steiner-Asiedu M, Armar-Klemesu M, Armah S. Population-based study of diabetic mellitus prevalence and its associated factors in adult Ghanaians in the greater Accra region. International Journal of Diabetes in Developing Countries. 2011;31(3):14953.

95. Paradies Y, Ben J, Denson N, Elias A, Priest N, Pieterse A, Gupta A, Kelaher M, Gee GJPo: Racism as a determinant of health: a systematic review and meta-analysis. 2015, 10(9):e0138511.

96. Organization WH. Definition and diagnosis of diabetes mellitus and intermediate hyperglycaemia: report of a WHO/IDF consultation. 2006.

97. Smith KJ, Béland M, Clyde M, Gariépy G, Pagé V, Badawi G, Rabasa-Lhoret R, Schmitz NJJopr: Association of diabetes with anxiety: a systematic review and meta-analysis. 2013, 74(2):89-99.

98. Sui H, Sun N, Zhan L, Lu X, Chen T, Mao XJPo. Association between work-related stress and risk for type 2 diabetes: a systematic review and meta-analysis of prospective cohort studies. 2016, 11(8).

99. Vancampfort D, Mugisha J, Hallgren M, De Hert M, Probst M, Monsieur D, Stubbs B. The prevalence of diabetes mellitus type 2 in people with alcohol use disorders: a systematic review and large scale meta-analysis. Psychiatry Res. 2016;246:394-400.

100. Willi C, Bodenmann P, Ghali WA, Faris PD, Cornuz J. Active smoking and the risk of type 2 diabetes: a systematic review and metaanalysis. Jama. 2007;298(22):2654-64.

101. Pieterse AL, Todd NR, Neville HA, Carter RT. Perceived racism and mental health among Black American adults: a meta-analytic review. Journal of Counseling Psychology. 2012;59(1):1.

102. Scammacca N, Roberts G, Stuebing KKJRoer. Meta-analysis with complex research designs: Dealing with dependence from multiple measures and multiple group comparisons. 2014, 84(3):328-364.

103. Cooper HM: Synthesizing research: A guide for literature reviews, vol. 2: Sage; 1998.

104. Higgins JP, Thompson SG, Deeks JJ, Altman DG. Measuring inconsistency in meta-analyses. BMJ: British Medical Journal. 2003;327(7414):557.

105. Higgins JP, Thompson SGJSim: Quantifying heterogeneity in a meta-analysis. 2002, 21(11):1539-1558.

106. Paradies Y, Priest N, Ben J, Truong M, Gupta A, Pieterse A, Kelaher M, Gee G: Racism as a determinant of health: a protocol for conducting a systematic review and meta-analysis. Systematic reviews 2013, 2(1):1.

107. Fu R, Gartlehner G, Grant M, Shamliyan T, Sedrakyan A, Wilt TJ, Griffith L, Oremus M, Raina P. Ismaila AJJoce: Conducting quantitative synthesis when comparing medical interventions: AHRQ and the Effective Health Care Program. 2011, 64(11):11871197.

108. Mohagheghi P, Conradi R: Vote-counting for combining quantitative evidence from empirical studies-an example. In: Proceedings of the International Symposium on Empirical Software Engineering (ISESE'04): 2004: Citeseer; 2004.

109. Bushman BJ, Wang MCJThors: Vote-counting procedures in meta-analysis. 1994, 236:193-213.

110. Egger M, Smith GD, Schneider M, Minder CJB. Bias in meta-analysis detected by a simple, graphical test. 1997, 315(7109):629634.

111. Rosenthal RJPb. The file drawer problem and tolerance for null results. 1979, 86(3):638.

112. Becker. BJJPbim-aP, assessment, adjustments: Failsafe $\mathbf{N}$ or file-drawer number. 2005:111-125. 
113. Hunter JE, Schmidt FL: Methods of meta-analysis: Correcting error and bias in research findings: Sage; 2004.

114. Duval S, Tweedie RJB. Trim and fill: a simple funnel-plot-based method of testing and adjusting for publication bias in metaanalysis. 2000, 56(2):455-463.

115. Manne-Goehler J, Montana L, Gómez-Olivé FX, Rohr J, Harling G, Wagner RG, Wade A, Kabudula CW, Geldsetzer P, Kahn K, et al. The ART Advantage: Health Care Utilization for Diabetes and Hypertension in Rural South Africa. J Acquir Immune Defic Syndr. 2017;75(5):561-7.

116. Mohamed HG, Mustafa K, Ibrahim SO, Åstrøm AN. Dietary habits, oral impact on daily performance and type 2 diabetes: A matched case-control study from Sudan. Health and Quality of Life Outcomes 2017, 15(1).

117. Sarfo-Kantanka O, Sarfo FS, Ansah EO, Yorke E, Akpalu J, Nkum BC, Eghan B. Frequency and determinants of thyroid autoimmunity in Ghanaian type 2 diabetes patients: A case-control study. BMC Endocrine Disorders 2017, 17(1).

118. Cook-Huynh M, Ansong D, Steckelberg RC, Boakye I, Seligman K, Appiah L, Kumar N, Amuasi JH. Prevalence of hypertension and diabetes mellitus in adults from a rural community in Ghana. Ethn Dis. 2012;22(3):347-52.

119. Oti SO, van de Vijver SJM, Agyemang C, Kyobutungi C. The magnitude of diabetes and its association with obesity in the slums of Nairobi, Kenya: Results from a cross-sectional survey. Tropical Medicine International Health. 2013;18(12):1520-30.

120. Ruhembe CC, Mosha TCE, Nyaruhucha CNM. Prevalence and awareness of type 2 diabetes mellitus among adult population in Mwanza city, Tanzania. Tanzania Journal of Health Research 2014, 16(2).

121. Silva-Matos C, Gomes A, Azevedo A, Damasceno A, Prista A, Lunet N. Diabetes in Mozambique: Prevalence, management and healthcare challenges. Diabetes Metabolism. 2011;37(3):237-44.

122. Maka J, Mbanya J-CJPAMJ. Risk factors of type 2 diabetes among Mbororo population of Guiwa-Yangamo village in the EastCameroon. 2017, 2(2).

123. Gezawa ID, Puepet FH, Mubi BM, Talle MA, Haliru I, Uloko AE, Bakki B. Socio-demographic and Anthropometric risk factors for Type 2 diabetes in Maiduguri, North-Eastern Nigeria. Sahel Medical Journal 2015, 18(5).

124. Sorsdahl K, Sewpaul R, Evans M, Naidoo P, Myers B, Stein DJ. The association between psychological distress, alcohol use and physical non-communicable diseases in a nationally representative sample of South Africans. Journal Of Health Psychology 2016:1359105316642832-1359105316642832.

125. Stanifer JW, Cleland CR, Makuka GJ, Egger JR, Maro V, Maro H, Karia F, Patel UD, Burton MJ, Philippin H. Prevalence, risk factors, and complications of diabetes in the Kilimanjaro region: A population-based study from Tanzania. PLoS ONE 2016, 11(10).

126. Chege MP. Risk factors for type 2 diabetes mellitus among patients attending a rural Kenyan hospital. African Journal of Primary Health Care and Family Medicine 2010, 2(1):Article 96-Article 96..

127. Ben J, Cormack D, Harris R, Paradies Y: Racism and health service utilisation: A systematic review and meta-analysis. PloS one 2017, 12(12):e0189900.

128. Noubiap JJ, Nansseu JR, Endomba FT, Ngouo A, Nkeck JR, Nyaga UF, Kaze AD, Bigna JJJSr: Active smoking among people with diabetes mellitus or hypertension in Africa: a systematic review and meta-analysis. 2019, 9(1):588.

129. one POSJP. Correction: A Systematic Review of Tobacco Smoking Prevalence and Description of Tobacco Control Strategies in Sub-Saharan African Countries; 2007 to 2014. 2016, 11(5):e0155572.

130. DeShazo JP, LaVallie DL. Wolf FMJBmi, making d: Publication trends in the medical informatics literature: 20 years of" Medical Informatics" in MeSH. 2009, 9(1):7.

131. Vazquez G, Duval S, Jacobs DR Jr, Silventoinen KJEr: Comparison of body mass index, waist circumference, and waist/hip ratio in predicting incident diabetes: a meta-analysis. 2007, 29(1):115-128.

132. Kodama S, Horikawa C, Fujihara K, Heianza Y, Hirasawa R, Yachi Y, Sugawara A, Tanaka S, Shimano H, lida KTJAjoe: Comparisons of the strength of associations with future type 2 diabetes risk among anthropometric obesity indicators, including waist-to-height ratio: a meta-analysis. 2012, 176(11):959-969.

133. Goedecke JH, Keswell D, Weinreich C, Fan J, Hauksson J, Victor H, Utzschneider K, Levitt NS, Lambert EV, Kahn SEJD. Ethnic differences in hepatic and systemic insulin sensitivity and their associated determinants in obese black and white South African women. 2015, 58(11):2647-2652.

134. Goedecke JH, Mtintsilana A, Dlamini SN. Kengne APJDr, practice c: Type 2 diabetes mellitus in African women. 2017, $123: 87-96$.

135. Goedecke JH, Levitt NS, Lambert EV, Utzschneider KM, Faulenbach MV, Dave JA, West S, Victor H, Evans J, Olsson TJO. Differential effects of abdominal adipose tissue distribution on insulin sensitivity in black and white South African women. 2009, 17(8):1506-

Page $21 / 27$ 
1512.

136. Sumner AE, Micklesfield LK, Ricks M, Tambay AV, Avila NA, Thomas F, Lambert EV, Levitt NS, Evans J, Rotimi CNJO. Waist circumference, BMI, and visceral adipose tissue in white women and women of African descent. 2011, 19(3):671-674.

137. Qiao Q, Nyamdorj RJEjocn. Is the association of type II diabetes with waist circumference or waist-to-hip ratio stronger than that with body mass index? 2010, 64(1):30-34.

138. Lee CMY, Huxley RR, Wildman RP, Woodward MJJoce: Indices of abdominal obesity are better discriminators of cardiovascular risk factors than BMl: a meta-analysis. 2008, 61(7):646-653.

139. Abdullah A, Peeters A, de Courten M. Stoelwinder JJDr, practice c: The magnitude of association between overweight and obesity and the risk of diabetes: a meta-analysis of prospective cohort studies. 2010, 89(3):309-319.

140. Aune D, Norat T, Leitzmann M, Tonstad S, Vatten LJ: Physical activity and the risk of type 2 diabetes: a systematic review and dose-response meta-analysis. In.: Springer; 2015.

141. Wahid A, Manek N, Nichols M, Kelly P, Foster C, Webster P, Kaur A, Friedemann Smith C, Wilkins E, Rayner MJJotAHA: Quantifying the association between physical activity and cardiovascular disease and diabetes: a systematic review and meta-analysis. 2016, 5(9):e002495.

142. Guthold R, Louazani SA, Riley LM, Cowan MJ, Bovet P, Damasceno A, Sambo BH, Tesfaye F, Armstrong TPJAjopm: Physical activity in 22 African countries: results from the World Health Organization STEPwise approach to chronic disease risk factor surveillance. 2011, 41(1):52-60.

143. Chida Y, Hamer M: An association of adverse psychosocial factors with diabetes mellitus: a meta-analytic review of longitudinal cohort studies. In.: Springer; 2008.

144. Ali S, Stone M, Peters J, Davies M, Khunti KJDM. The prevalence of co-morbid depression in adults with Type 2 diabetes: a systematic review and meta-analysis. 2006, 23(11):1165-1173.

145. Baliunas DO, Taylor BJ, Irving H, Roerecke M, Patra J, Mohapatra S, Rehm JJDc: Alcohol as a risk factor for type 2 diabetes: a systematic review and meta-analysis. 2009, 32(11):2123-2132.

146. Koppes LL, Dekker JM, Hendriks HF, Bouter LM, Heine RJJDc. Moderate alcohol consumption lowers the risk of type 2 diabetes: a meta-analysis of prospective observational studies. 2005, 28(3):719-725.

147. Sundararajan K, Campbell MK, Choi Y-H, Sarma SJJotACoN. The relationship between diet quality and adult obesity: evidence from Canada. 2014, 33(1):1-17.

148. van Wyk HJ, Davis RE, Davies JS. A critical review of low-carbohydrate diets in people with Type 2 diabetes. Diabet Med. 2016;33(2):148-57.

149. Van Zyl MK, Steyn NP, Marais ML. Characteristics and factors infuencing fast food intake of young adult consumers in Johannesburg, South Africa. South African Journal of Clinical Nutrition. 2010;23(3):124-30.

150. Schmitt MT, Branscombe NR, Postmes T, Garcia AJPb. The consequences of perceived discrimination for psychological well-being: A meta-analytic review. 2014, 140(4):921.

151. Gill GV, Mbanya JC, Ramaiya KL, Tesfaye S. A sub-Saharan African perspective of diabetes. Diabetologia. 2009;52(1):8-16.

\section{Figures}




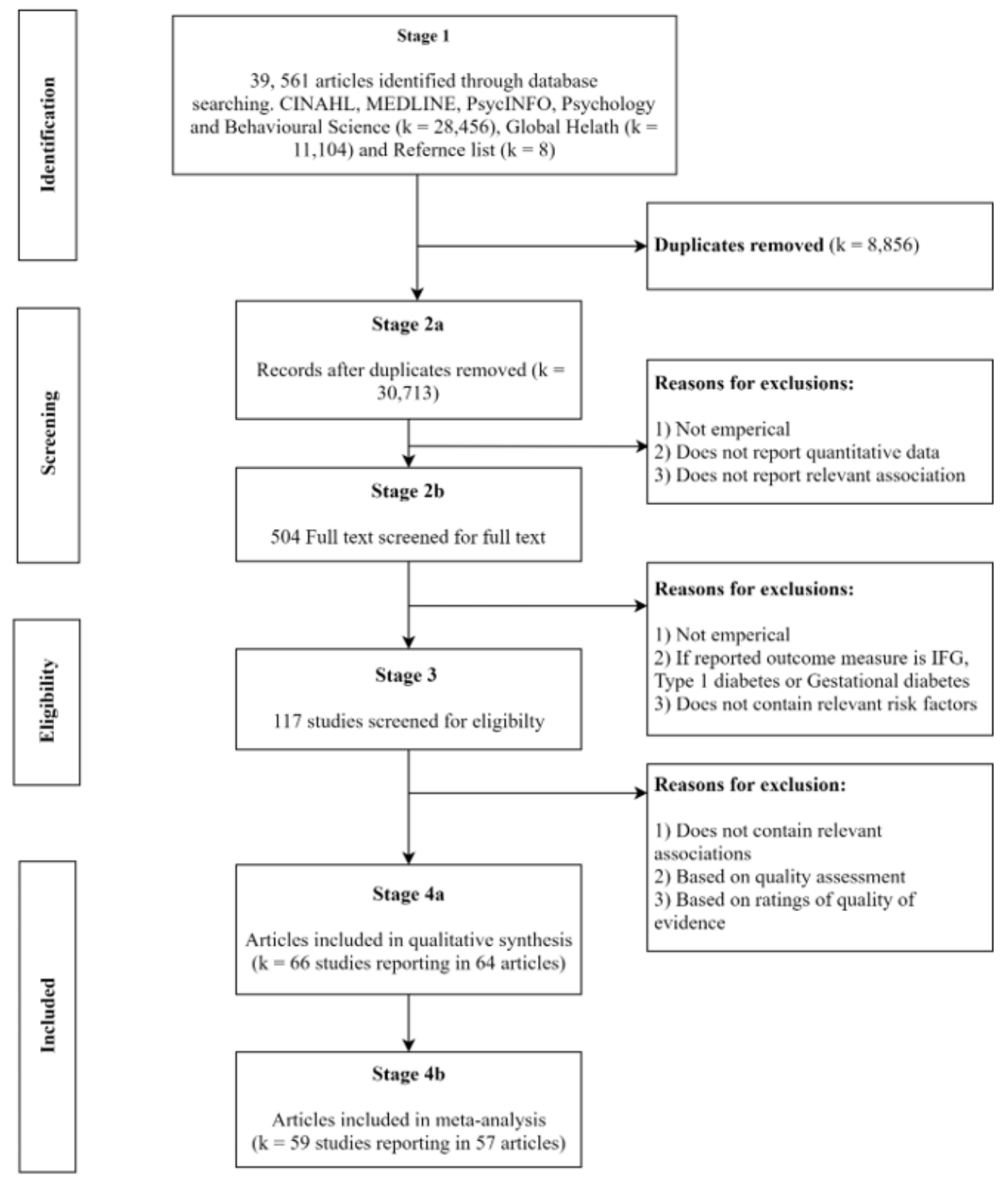

Figure 1

PRISMA screening process flowchart. 
Study name

Abebe et al. 2014

Abebe et al. 2016

Alsdeniyi et al. 2017

Ali et al. 2012

Alkor and Emem-Chiome, 2015

Arsya, Mis tire and Dawit, 2010

Arugu and Maduka, 2017

Bahendeka et al. 2016

Bsileyet al. 2016. Study 1

Baileyet al. 2016. Study 2

Bas tawrous et al. 2017

Bello-Ovosi et al. 2018

Chege, 2010

Chiwangs et al. 2018

Divals et al. 2018

DubozP et al. 2012

DubozP, et al.2017

Ekpenyong et al. 2012

Elmadhoun et al. 2016

Etukumana, Puepet and Obadofin, 2014

Faumolt-Jeps en et al. 2014

Gazawa et al. 2015

Gazawa et al. 2016

Gudjinu and Sarfo, 2017

Habtewold, Tsege \& Wale, 2016

Is a et al. 2016

Is ars \& Oxundis, 2015

Katchung et al. 2016

Kingue et 9.2017

Kyari et al. 2014

Maher et al. 2011

Maks et al. 2017

Mathenge et al. 2014

Mayega et al. 2013

Mbamukonka, P. K. et al. 2017

Millogo, T. et al. 2018

Nyenwe et al. 2003

Oti et al. 2013

Qwiti et al. 2017

Rguibi and Belahs en, 2008

Seck, D.M et al. 2015

Silva-Matos et al. 2011

Stanifer et al. 2016

Tarekegne, F. E., et al. 2018 Study 1

Tarekegne, F. E., et al. 2018 Study 2

Tes faye et al. 2018
Statistics for each study

Odds Lower Upper

ratio limit limit Z-Value p-Value

$\begin{array}{lllll}2.427 & 1.403 & 4.199 & 3.170 & 0.002\end{array}$

$\begin{array}{lllll}2.286 & 0.596 & 8.609 & 1.201 & 0.230\end{array}$

$\begin{array}{lllll}2.457 & 1.745 & 3.481 & 5.145 & 0.000\end{array}$

$\begin{array}{lllll}5.117 & 2.419 & 10.824 & 4.271 & 0.000\end{array}$

$\begin{array}{lllll}4.626 & 0.845 & 25.342 & 1.785 & 0.078\end{array}$

$\begin{array}{lllll}2.389 & 1.398 & 4.015 & 3.203 & 0.001\end{array}$

$\begin{array}{lllll}3.601 & 1.728 & 7.503 & 3.421 & 0.001\end{array}$

$\begin{array}{lllll}2.248 & 1.010 & 5.002 & 1.985 & 0.047\end{array}$

$\begin{array}{lllll}2938 & 2531 & 3.411 & 14.148 & 0.000\end{array}$

$\begin{array}{lllll}2.504 & 2118 & 2.960 & 10.752 & 0.000\end{array}$

$\begin{array}{lllll}4.331 & 2.655 & 7.083 & 5.873 & 0.000\end{array}$

$\begin{array}{lllll}1.851 & 0.626 & 5.472 & 1.113 & 0.268\end{array}$

$\begin{array}{lllll}2.295 & 0.938 & 5.616 & 1.819 & 0.069\end{array}$

$\begin{array}{lllll}1.428 & 0.811 & 2.517 & 1.233 & 0.217\end{array}$

$\begin{array}{lllll}1.347 & 0.447 & 4.081 & 0.529 & 0.597\end{array}$

$\begin{array}{lllll}3.826 & 2.132 & 6.887 & 4.498 & 0.000\end{array}$

$\begin{array}{lllll}2.293 & 0.868 & 6.074 & 1.870 & 0.095\end{array}$

$\begin{array}{lllll}1.360 & 1.118 & 1.630 & 3.118 & 0.002\end{array}$

$\begin{array}{lllll}2.420 & 1.843 & 3.176 & 6.385 & 0.000\end{array}$

$\begin{array}{lllll}1.281 & 0.707 & 2.320 & 0.816 & 0.415\end{array}$

$\begin{array}{lllll}1.514 & 0.753 & 3.042 & 1.164 & 0.244\end{array}$

$\begin{array}{lllll}0.520 & 0.080 & 3.384 & -0.684 & 0.494\end{array}$

$\begin{array}{lllll}2.276 & 0.939 & 5.516 & 1.821 & 0.069\end{array}$

$\begin{array}{lllll}3.007 & 0.681 & 13.269 & 1.454 & 0.148\end{array}$

$\begin{array}{lllll}1.488 & 1.023 & 2.163 & 2.080 & 0.038\end{array}$

$\begin{array}{lllll}1.130 & 0.782 & 1.633 & 0.850 & 0.515\end{array}$

$\begin{array}{lllll}3.489 & 1.638 & 7.439 & 3.234 & 0.001\end{array}$

$\begin{array}{lllll}3.199 & 1.718 & 5.969 & 3.685 & 0.000\end{array}$

$\begin{array}{lllll}0.831 & 0.607 & 1.138 & -1.155 & 0.248\end{array}$

$\begin{array}{lllll}3.587 & 1.758 & 7.236 & 3.523 & 0.000\end{array}$

$\begin{array}{lllll}5.536 & 2.035 & 15.060 & 3.352 & 0.001\end{array}$

$\begin{array}{lllll}1.255 & 0.231 & 6.828 & 0.262 & 0.793\end{array}$

$\begin{array}{lllll}2208 & 1.623 & 3.003 & 5.046 & 0.000\end{array}$

$\begin{array}{lllll}2.698 & 1.538 & 4.733 & 3.455 & 0.001\end{array}$

$\begin{array}{lllll}22.683 & 8.550 & 60.174 & 6.271 & 0.000\end{array}$

$1.985-1.337 \quad 2.887 \quad 3.438$

$\begin{array}{lllll}5.032 & 1.107 & 22.863 & 2.092 & 0.038\end{array}$

$\begin{array}{lllll}2.482 & 1.629 & 3.721 & 4.277 & 0.000\end{array}$

$\begin{array}{lll}1.998 & 0.297 & 13.448\end{array}$

$\begin{array}{lllll}5.740 & 0.588 & 58.058 & 1.480 & 0.139\end{array}$

$\begin{array}{lllll}1.680 & 1.379 & 1.999 & 5.347 & 0.000\end{array}$

$\begin{array}{lllll}2974 & 1.709 & 5.175 & 3.857 & 0.000\end{array}$

$\begin{array}{lllll}2.811 & 1.258 & 6.294 & 2.514 & 0.012\end{array}$

$\begin{array}{lllll}3.090 & 1.793 & 5.325 & 4.062 & 0.000\end{array}$

$\begin{array}{lllll}2.225 & 1.079 & 4.587 & 2.167 & 0.030\end{array}$

$\begin{array}{rrrrr}16.115 & 6.817 & 38.093 & 6.333 & 0.000\end{array}$

$\begin{array}{lllll}2.425 & 2.082 & 2.824 & 11.394 & 0.000\end{array}$
Odds ratio and $95 \% \mathrm{Cl}$

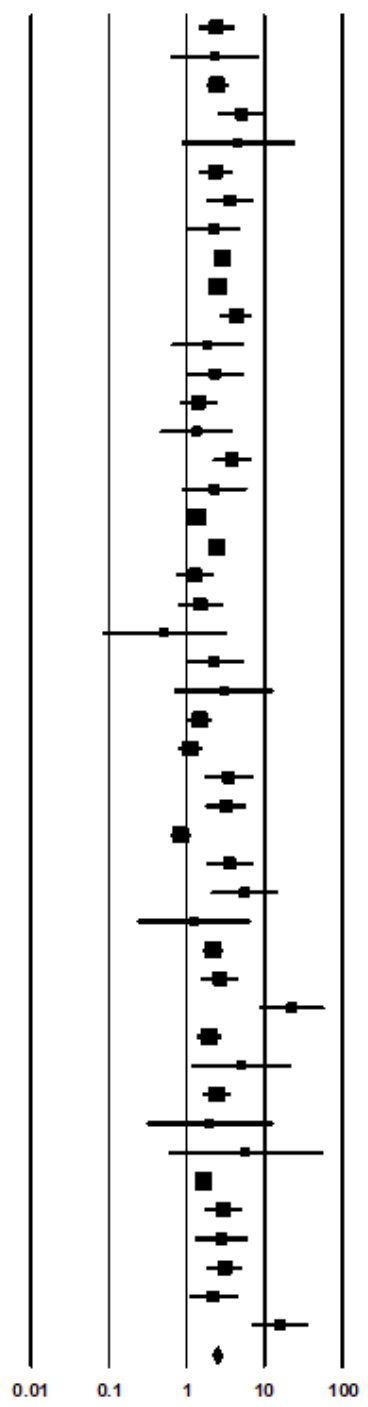

\section{Figure 2}

Forest plot of the effect sizes for overall body weight indicators included in the meta-analysis 
Abebe et al. 2014

Abebe et al. 2018

Aladeniyiet al. 2017

Ali et sl. 2012

Alik $\alpha$ and Emem-Chiorre, 2015

Arsya, Mis tire and Daw it, 2010

Arugu and Maduka, 2017

Bahendeka et al. 2018

Bailey et al. 2016. Study 1

Bailey et al. 2016. Study 2

Bestaw rous et al. 2017

Bello-Oros iet al. 2018

Chege, 2010

Chiw anga et al 2016

Divals et al. 2016

Duboz $P$ et al. 2012

Emodhoun et al. 2016

Eukumana, Puepet and Obadof in, 2014

Faurholt-Jeps en et al. 2014

Gazaw a et al. 2016

Gudjinu and Sarfo, 2017

Habtew old, Ts ega \& Wale, 2018

isa et 91.2018

ksarg \& Okundia, 2015

Katchung et al. 2016

Kingue et $\mathrm{s.} 2017$

Kyari et al. 2014

Maher et al. 2011

Mathenge et al. 2014

Mayega et al. 2013

Mbamukonka, P. K et al 2017

Millogo, T. et al. 2018

Nyenwe et al. 2003

Oti et al. 2013

Ow iti et al. 2017

Rguibi and Belahsen, 2006

Silve-Matos et al. 2011

Stanifer et al. 2016

Tarekegne, F. E, et al. 2018 Study 1

Tarekegne, F. E, et al. 2018 Study 2

Tesfaye et al. 2016

\begin{tabular}{|c|c|c|c|c|}
\hline $\begin{array}{l}\text { Odds } \\
\text { ratio }\end{array}$ & $\begin{array}{l}\text { Lower } \\
\text { lim it }\end{array}$ & $\begin{array}{l}\text { Upper } \\
\text { lim it }\end{array}$ & Z-Value & p-Value \\
\hline 2.427 & 1.403 & 4.199 & 3.170 & 0.002 \\
\hline 2.268 & 0.596 & 8.609 & 1.201 & 0.230 \\
\hline 2.457 & 1.745 & 3.461 & 5.145 & 0.000 \\
\hline 5.117 & 2.419 & 10.824 & 4.271 & 0.000 \\
\hline 5.480 & 0.831 & 36.143 & 1.788 & 0.077 \\
\hline 2.973 & 1.654 & 5.343 & 3.643 & 0.000 \\
\hline 4.149 & 2.079 & 8.281 & 4.038 & 0.000 \\
\hline 1.597 & 0.681 & 3.854 & 1.041 & 0.298 \\
\hline 2938 & 2.531 & 3.411 & 14.148 & 0.000 \\
\hline 2504 & 2.118 & 2.960 & 10.752 & 0.000 \\
\hline 4.331 & 2.655 & 7.063 & 5.873 & 0.000 \\
\hline 1.627 & 0.581 & 4.715 & 0.896 & 0.370 \\
\hline 1.435 & 0.622 & 3.307 & 0.847 & 0.397 \\
\hline 1.700 & 0.928 & 3.114 & 1.718 & 0.088 \\
\hline 1.387 & 0.395 & 4.877 & 0.511 & 0.610 \\
\hline 3.828 & 2.132 & 6.867 & 4.498 & 0.000 \\
\hline 2.228 & 1.447 & 3.429 & 3.641 & 0.000 \\
\hline 1.428 & 0.517 & 3.942 & 0.687 & 0.492 \\
\hline 1.213 & 0.644 & 2.282 & 0.597 & 0.550 \\
\hline 2.421 & 0.826 & 7.098 & 1.612 & 0.107 \\
\hline 3.007 & 0.681 & 13.289 & 1.454 & 0.148 \\
\hline 1.488 & 1.023 & 2163 & 2.080 & 0.038 \\
\hline 1.130 & 0.782 & 1.633 & 0.850 & 0.515 \\
\hline 3.489 & 1.636 & 7.439 & 3.234 & 0.001 \\
\hline 2830 & 1.451 & 5.519 & 3.051 & 0.002 \\
\hline 1.215 & 0.761 & 1.940 & 0.817 & 0.414 \\
\hline 3.567 & 1.758 & 7.238 & 3.523 & 0.000 \\
\hline 6.795 & 2.330 & 19.815 & 3.509 & 0.000 \\
\hline 2.208 & 1.623 & 3.003 & 5.048 & 0.000 \\
\hline 2.696 & 1.536 & 4.733 & 3.455 & 0.001 \\
\hline 22.883 & 8.550 & 60.174 & 6.271 & 0.000 \\
\hline 2.082 & 1.376 & 3.152 & 3.468 & 0.001 \\
\hline 2.541 & 1.188 & 5.433 & 2.404 & 0.016 \\
\hline 1.998 & 1.225 & 3.258 & 2.773 & 0.008 \\
\hline 1.998 & 0.297 & 13.448 & 0.712 & 0.477 \\
\hline 3.512 & 0.409 & 30.147 & 1.145 & 0.252 \\
\hline 3.880 & 2.387 & 6.361 & 5.375 & 0.000 \\
\hline 2811 & 1.256 & 6.294 & 2.514 & 0.012 \\
\hline 3.210 & 1.907 & 5.404 & 4.388 & 0.000 \\
\hline 2.253 & 0.958 & 5.296 & 1.863 & 0.063 \\
\hline .785 & 7.980 & 54.142 & 6.212 & 0.000 \\
\hline & 2.229 & 3.001 & 12.530 & 0.00 \\
\hline
\end{tabular}

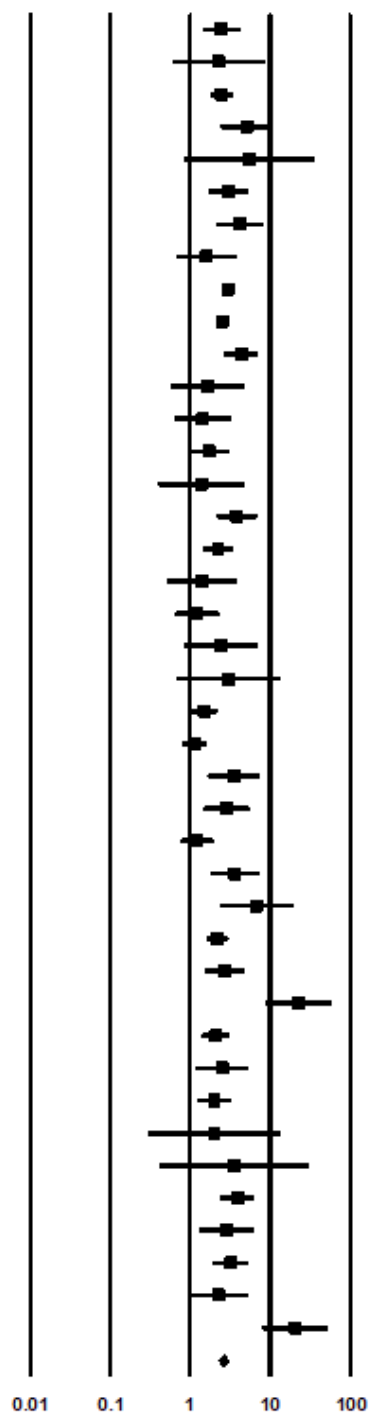

\section{Figure 3}

Forest plot of the effect sizes for combined BMI indices (BMI-OV, BMI-OV/OB, BMI-OB) 
Study name

Seck D.M et al. 2015

Alikor and Emem-Chioma, 2015

Araya, Mstire and Daw it, 2010

Bahendeka et al. 2016

Chege, 2010

Chiw anga et al. 2016

Divala et al. 2016

Ekpenyong et al. 2012

Emadhoun et al. 2016

Arugu and Maduka, 2017

Faurholt-Jepsen et al. 2014

Katchung et al. 2016

Kingue et a. 2017

Maher et al. 2011

Nyenw e et al. 2003

Oti et al. 2013

Rguibi and Belahsen, 2006

Silva-Matos et al. 2011

Tesfaye et al. 2016

Bello-Orosi et al. 2018

Duboz P, et al.2017

Millogo, T. et al. 2018

Eukumana, Puepet and Obadof in, 2014

Tar ekegne, F. E, et al. 2018 Study 1

Tarekegne, F. E, et al. 2018 Study 2

Gazaw a et al. 2016

Maka et al. 2017
Statis tics for each study

$\begin{array}{rrrrr}\begin{array}{c}\text { Odds } \\ \text { ratio }\end{array} & \begin{array}{c}\text { Lower } \\ \text { limit }\end{array} & \begin{array}{r}\text { Upper } \\ \text { limit }\end{array} & \text { Z-Value } & \text { p-Value } \\ 1.660 & 1.379 & 1.999 & 5.347 & 0.000 \\ 3.905 & 0.878 & 17.366 & 1.789 & 0.074 \\ 1.887 & 1.189 & 2.995 & 2.695 & 0.007 \\ 4.457 & 2.435 & 8.160 & 4.844 & 0.000 \\ 3.670 & 1.418 & 9.501 & 2.680 & 0.007 \\ 1.200 & 0.710 & 2.028 & 0.681 & 0.496 \\ 1.270 & 0.630 & 2.560 & 0.668 & 0.504 \\ 1.350 & 1.118 & 1.630 & 3.118 & 0.002 \\ 2.556 & 1.800 & 3.630 & 5.243 & 0.000 \\ 3.126 & 1.440 & 6.783 & 2.883 & 0.004 \\ 1.889 & 0.885 & 4.032 & 1.645 & 0.100 \\ 4.090 & 2.437 & 6.863 & 5.334 & 0.000 \\ 0.609 & 0.399 & 0.930 & -2.296 & 0.022 \\ 4.203 & 1.234 & 14.315 & 2.296 & 0.022 \\ 9.966 & 1.347 & 73.731 & 2.252 & 0.024 \\ 3.035 & 2.206 & 4.177 & 6.817 & 0.000 \\ 9.382 & 0.796 & 110.598 & 1.779 & 0.075 \\ 2.280 & 1.242 & 4.186 & 2.659 & 0.008 \\ 9.687 & 5.199 & 18.047 & 7.153 & 0.000 \\ 2.395 & 0.779 & 7.360 & 1.525 & 0.127 \\ 2.293 & 0.866 & 6.074 & 1.670 & 0.095 \\ 1.749 & 1.273 & 2.403 & 3.449 & 0.001 \\ 1.210 & 0.582 & 2.518 & 0.510 & 0.610 \\ 2.974 & 1.687 & 5.241 & 3.769 & 0.000 \\ 2.197 & 1.252 & 3.855 & 2.744 & 0.006 \\ 1.428 & 0.317 & 6.430 & 0.464 & 0.642 \\ 1.255 & 0.231 & 6.828 & 0.262 & 0.793 \\ 2.241 & 1.796 & 2.795 & 7.156 & 0.000\end{array}$

Odds ratio and $95 \% \mathrm{Cl}$

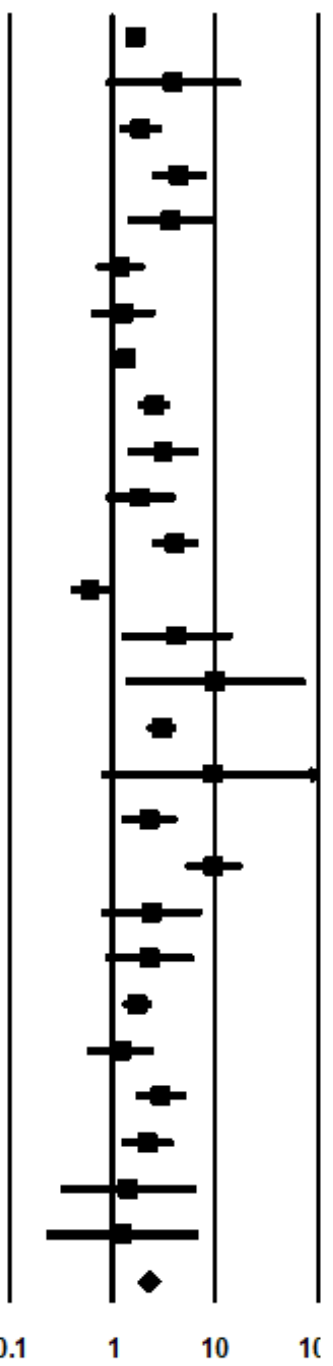

Figure 4

Forest plot of the effect sizes for Central obesity indices (WC \& WHR) 


\begin{tabular}{|c|c|c|c|c|c|}
\hline & $\begin{array}{l}\text { Odds } \\
\text { ratio }\end{array}$ & $\begin{array}{c}\text { Lower } \\
\text { limit }\end{array}$ & $\begin{array}{c}\text { Upper } \\
\text { limit }\end{array}$ & Z-Value & p-Value \\
\hline A bebe et al. 2016 & 4.890 & 1.229 & 19.460 & 2.252 & 0.024 \\
\hline Aladeniy i et al. 2017 & 2.768 & 1.929 & 3.970 & 5.530 & 0.000 \\
\hline Ali et al. 2012 & 6.105 & 2.445 & 15.246 & 3.875 & 0.000 \\
\hline A likor and Emem Chioma, 2015 & 6.896 & 0.715 & 66.463 & 1.670 & 0.095 \\
\hline Bahendeka et al. 2016 & 3.289 & 1.479 & 7.312 & 2.920 & 0.003 \\
\hline Bailey et al. 2016. Study 1 & 3.820 & 3.271 & 4.461 & 16.928 & 0.000 \\
\hline Bailey et al. 2016. Study 2 & 3.000 & 2.562 & 3.513 & 13.645 & 0.000 \\
\hline Bastaw rous et al. 2017 & 4.460 & 2.671 & 7.449 & 5.714 & 0.000 \\
\hline Bello-Or osi et al. 2018 & 1.164 & 0.400 & 3.383 & 0.278 & 0.781 \\
\hline Chege, 2010 & 1.435 & 0.622 & 3.307 & 0.847 & 0.397 \\
\hline Divala et al. 2016 & 1.540 & 0.335 & 7.076 & 0.555 & 0.579 \\
\hline Duboz P et al. 2012 & 4.247 & 2.184 & 8.258 & 4.262 & 0.000 \\
\hline Emadhoun et al. 2016 & 2.612 & 1.675 & 4.074 & 4.235 & 0.000 \\
\hline Eukumana, Puepet and Obadofin, 2014 & 1.843 & 0.600 & 5.659 & 1.068 & 0.285 \\
\hline Gudjinu and Sarfo, 2017 & 6.600 & 1.247 & 34.924 & 2.220 & 0.026 \\
\hline Isara \& Okundia, 2015 & 4.934 & 2.200 & 11.065 & 3.873 & 0.000 \\
\hline Katchung et al. 2016 & 3.690 & 1.701 & 8.005 & 3.304 & 0.001 \\
\hline Kingue et a. 2017 & 1.301 & 0.824 & 2.054 & 1.130 & 0.258 \\
\hline Ky ari et al. 2014 & 4.240 & 2.021 & 8.895 & 3.821 & 0.000 \\
\hline Maher et al. 2011 & 9.990 & 2.161 & 46.181 & 2.947 & 0.003 \\
\hline Mathenge et al. 2014 & 2.411 & 1.740 & 3.341 & 5.289 & 0.000 \\
\hline Mayega et al. 2013 & 4.033 & 2.212 & 7.351 & 4.552 & 0.000 \\
\hline Millogo, T. et al. 2018 & 2.744 & 1.721 & 4.376 & 4.241 & 0.000 \\
\hline Oti et al. 2013 & 2.950 & 1.727 & 5.040 & 3.960 & 0.000 \\
\hline Owiti et al. 2017 & 3.106 & 0.343 & 28.094 & 1.009 & 0.31 \\
\hline Rguibi and Belahsen, 2006 & 4.658 & 0.585 & 37.109 & 1.453 & 0.14 \\
\hline Tarekegne, F. E, et al. 2018 Study 1 & 4.240 & 2.402 & 7.485 & 4.981 & 0.000 \\
\hline Tarekegne, F. E, et al. 2018 Study 2 & 2.700 & 1.209 & 6.027 & 2424 & 0.01 \\
\hline \multirow[t]{2}{*}{ Tesf aye et al. 2016} & 37.949 & 11.784 & 122.211 & 6.094 & 0.00 \\
\hline & 3.220 & 2.730 & 3.798 & 13.886 & \\
\hline
\end{tabular}

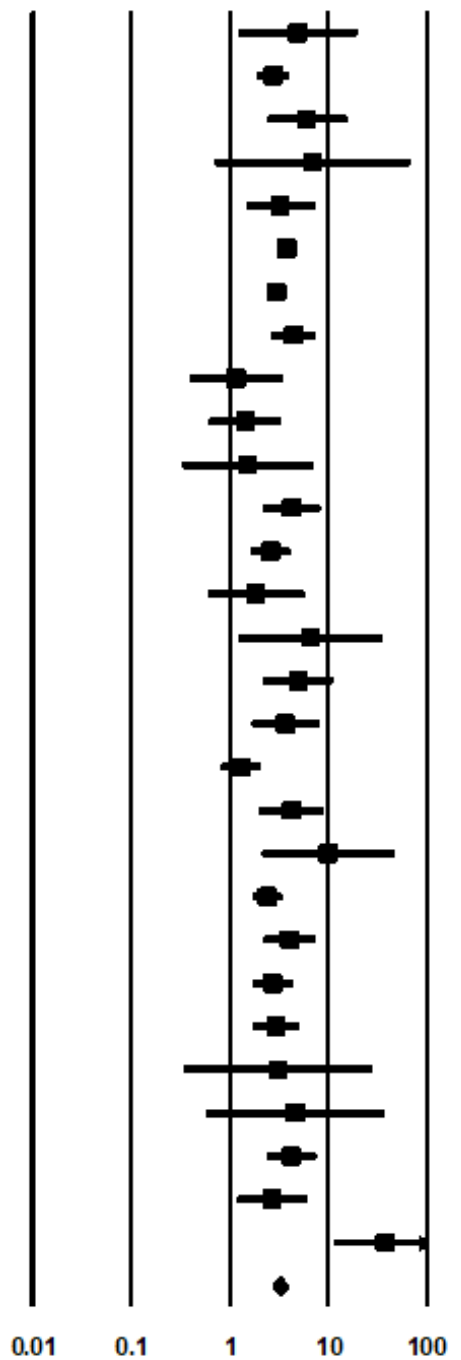

Figure 5

Forest plot of the effect sizes for individual studies: Obesity

\section{Supplementary Files}

This is a list of supplementary files associated with this preprint. Click to download.

- supplement1.doc

- supplement2.docx

- supplement3.docx

- supplement4.docx

- supplement5.docx 